\title{
Bovine Immunology: Implications for Dairy Cattle
}

\author{
Anastasia N. Vlasova* and Linda J. Saif* \\ Center for Food Animal Health, Ohio Agricultural Research and Development Center, Department of Animal Sciences, College of \\ Food, Agricultural and Environmental Sciences, The Ohio State University, Wooster, OH, United States
}

The growing world population (7.8 billion) exerts an increased pressure on the cattle industry amongst others. Intensification and expansion of milk and beef production inevitably leads to increased risk of infectious disease spread and exacerbation. This indicates that improved understanding of cattle immune function is needed to provide optimal tools to combat the existing and future pathogens and improve food security. While dairy and beef cattle production is easily the world's most important agricultural industry, there are few current comprehensive reviews of bovine immunobiology. Highyielding dairy cattle and their calves are more vulnerable to various diseases leading to shorter life expectancy and reduced environmental fitness. In this manuscript, we seek to fill this paucity of knowledge and provide an up-to-date overview of immune function in cattle emphasizing the unresolved challenges and most urgent needs in rearing dairy calves. We will also discuss how the combination of available preventative and treatment strategies and herd management practices can maintain optimal health in dairy cows during the transition (periparturient) period and in neonatal calves.

Keywords: bovine, immune responses, infectious diseases, dairy cows, neonatal calves, cattle

\section{INTRODUCTION}

Early fetal and neonatal calf mortality is a major contributor to increased production costs. Also, during the transition period ( $\sim 3$ weeks prior to and $\sim 3$ weeks after calving), dairy cows experience immune and metabolic dysregulation, that makes them very vulnerable to various infectious and non-infectious diseases. Despite the widespread availability of vaccines and antimicrobial compounds, several infectious diseases continue causing substantial morbidity, mortality, and economic loss to the cattle industry. To maintain optimal health in a cattle herd it is critical to understand mechanisms of natural anti-infectious immunity and how vaccination, biosecurity, nutrition, husbandry and calf management practices should be used to maintain and enhance immune protection. The advent of new high-throughput sequencing technologies and the publication of the complete bovine genome (in 2009) have boosted research that significantly enhanced our knowledge of the immune response in cattle. While this novel knowledge is being used actively for breeding and selection of cattle with desired performance and health traits, methods to genetically improve infectious disease resistance do not exist yet (1).

Mycobacterium and mammary gland (mastitis) infections represent two major threats impacting global cattle production and reaching $\$ 35$ billion in annual costs globally $(2,3)$. Respiratory infections are commonly associated with multiple pathogens and therefore referred to as bovine 
respiratory disease (BRD) complex (4). They are the principal source of significant economic losses for the North American beef and dairy industries. A number of bacteria and viruses are known to be associated with BRD in combination with other stress factors including heat, cold, fatigue, inadequate hydration or nutrition, injury or environmental dust contamination $(4,5)$. Similarly, several viral and bacterial pathogens are known to cause severe enteric diseases in calves and adult cattle. The major pathogens associated with scours are bovine coronavirus, bovine rotavirus, bovine viral diarrhea virus, salmonella spp. (multiple serotypes Dublin, Heidelberg, and Newport), Escherichia coli K99, cryptosporidia and Clostridium perfringens (6-8). With majority of vaccines against enteric pathogens having low efficacy or lacking broad protection, the threat of antimicrobial resistance (AMR) and ensuing decrease in the use of antimicrobials and often multi-agent nature of scours, maintaining a healthy herd can become a challenge.

Other pathogens of significance to the cattle industry include foot and mouth disease virus (FMDV) - one of the most contagious and wide-spread viruses known that can infect multiple species including humans (9); bovine leukemia virus $(\mathrm{BLV})$, paratuberculosis, cryptosporidiosis, leptospirosis and brucellosis (10-12). Besides impacting cattle production, a large number of bacterial (leptospirosis, brucellosis) and some viral $(\mathrm{BCoV}, \mathrm{BRV})$ pathogens are associated with zoonoses that can cause diverse and sometimes severe diseases in humans (13).

Thus, maintaining cattle health is of utmost importance for national and global food security and human well-being. Dairy cows and calves are most significantly impacted by the industry demands whereby the young are separated from the cows almost immediately after birth and cows are bred as frequently as possible to increase milk production. Such practices lead to physiological stress and suboptimal immune function in cows and high vulnerability of their calves. Thus, an in-depth and comprehensive understanding of the immune function of these important livestock animals in the context of the current herd management practices is needed.

\section{INNATE IMMUNITY}

In cattle, like in many other animals, the first line of defense is represented by physical barriers and mechanisms including skin and mucosal membranes, as well as elimination of invading microorganisms by coughing, sneezing, vomiting and diarrhea. Besides forming mechanical barriers of the respiratory, gastrointestinal and urogenitary tracts, epithelial cells secrete a number of antimicrobial factors, including antimicrobial peptides and defensins, and thus play an important role in the innate immune response. The other known critical cellular components of the innate immune system in cattle include neutrophils; natural killer cells, NK; dendritic cells, DC; gamma delta $\mathrm{T}$ cells $(\gamma \delta \mathrm{T})$; mucosa-associated invariant $\mathrm{T}$ cells (MAITs); macrophages, $\mathrm{M} \phi$, and granulocytes. While the majority of information on their development and function comes from human and mouse studies, the available data for cattle were derived from studies on mastitis, tuberculosis, BVDV, FMDV, BHV-1, and BRSV (9, 14-16). Unique to cattle, newborn calves have unusually high numbers of circulating $\gamma \delta \mathrm{T}$ cells (up to $60 \%$ of the lymphocyte pool), and $\gamma \delta \mathrm{T}$ cells of ruminants express WC-1 antigen whose function is unknown [may act as microbial/pathogens pattern recognition (PPR)] (14). This can be a compensatory response that balances out the immaturity of neutrophil, macrophage and DC functions in neonatal calves (17). With the exception of NK cells, the presence of innate lymphoid cells (ILCs) - another important subset of the innate immune cells - has not been confirmed in cattle thus far (9).

These diverse immune cell subsets are equipped with PPR molecules that interact with pathogen-associated molecular patterns (PAMPs) during the initial stages of the immune response (14). The best characterized among PPRs are toll-like receptors (TLRs). Ten TLRs with diverse and sometimes overlapping PAMP affinities have been confirmed in cattle (18). TLR1 recognizes triacyl lipopeptide of mycobacteria; TLR2 - peptidoglycans of gram-positive organisms and lipoarbinomannan of mycobacteria and zymosan of fungi; TLR3 - dsRNA; TLR4 - lipopolysaccharide, LPS; TLR5 flagellin; TLR6 - diacyl-lipopeptides of mycoplasma; TLR7 and 8 - single-stranded RNA (ssRNA); TLR9 - CpG; while TLR10 function and affinity have not yet been fully assessed (18). Prior to binding to TLR4, LPS, a bacterial component of H. somni, M. haemolytica, and P. multocida, interacts with LPS binding protein, soluble CD14, and the TLR4 cofactor MD2. TLR4 also recognizes and binds the $\mathrm{F}$ protein of RSV. In addition to TLR3,7-9, BHV-1, PIV-3, BRSV, and BVDV can recognize and interact with cytosolic viral pathogen recognition receptors, retinoic acid-induced gene-I (RIG-I), and melanoma differentiation associated gene-5 (MDA-5). These interactions lead to TLR-independent activation of NF-kappa B and IRF-3 and -7 via mitochondrial antiviral signaling adaptor (MAVS), interferon-beta promoter stimulator (IPS-1), virus-inducing signaling adaptor, and Cardif (14).

Upon activation of the local effector cells (endothelial cells, epithelial cells, $M \phi$, and DCs) of the innate immune system by inflammatory cytokines [IL1, tumor necrosis factor alpha (TNF $\alpha$ ), and IL6], they produce a number of cytokines and chemokines that attract migration of neutrophils and monocytes into the affected area. They in turn signal to recruit to DCs and NK, T, and B cells. In contrast, IL4, IL10, and IL17 actively promote the resolution of the inflammatory cascade (19).

Bovine mast cells - a heterogenous group of cells in mucosa, skin, mammary gland and other organs that play a pivotal role in allergic and inflammatory responses by secreting biologically active substances including histamine, leukotrienes, plateletactivating factors (PAF) and prostaglandins (20-22). While immunohistochemical and functional heterogeneity of mast cells in bovines is poorly characterized, it is known that their distribution and frequency vary per anatomical site, with age and animal health. Evaluation of mast cell functions associated with chymase and tryptase production has further confirmed their anatomical compartmentalization (20). 
Inflammatory chemokines include IL8 (CXCL8), GCP-2 (CXCL6), ENA-78 (CXCL5), Gro (CXCL1-3), IP-10 (CXCL10), I-Tac (CXCL11), RANTES (CCL5), MIP-alpha (CCL3) and -beta (CCL4), MCP 1-5 (CCL7, 8, 12, 13), and eotaxins 1-3 (CCL24, 26) depending on the stimulus with receptors that include CXCR1, 2, and 3 and CCR1, 2, 3, and 5. Lymphocytes that home to mucosal tissues use a different set of chemokines (e.g., naïve cells express CCR1-10, CSCR1-3 and memory cells express CCR8-10, CSCR1, 2, 4, and 5). Chemerin acts as a chemotactic factor for DCs and macrophages.

Oxylipids are another important class of immune molecules derived from cellular lipids that regulate the onset, magnitude, duration and resolution of the inflammatory response. Oxylipids are synthesized from polyunsaturated fatty acids [n-6 (omega-6) linoleic and arachidonic acids or the $\mathrm{n}-3$ eicosapentaenoic and docosahexaenoic acids] (23). These fatty acid substrates are oxidized non-enzymatically by reactive oxygen species (ROS) or enzymatically by different cyclooxygenases, lipoxygenases, and cytochrome $\mathrm{P} 450$ producing a variety of oxylipids including prostaglandins, thromboxanes, leukotrienes, and lipoxins (24).

Natural Abs (NAbs) are an important humoral component of innate immunity. They are mostly IgM (and some IgG and IgA) Abs produced without antigenic stimulation by B1-B cells and play an essential role in primary immune response (25). A high proportion of NAbs binds to PAMPs with relatively low affinity. Complement activation by the classical pathway is one of the most important NAb functions.

Complement is another significant mechanism of innate immune defense. It consists of a group of proteins (C1-C9) present in serum in an inactive form that is activated by antigenAb complexes (classical pathway) or by some carbohydrates (lectin pathway) or by a variety of surfaces that are not protected by natural inhibitors (alternative pathway). The classical pathway is initiated by the activation of $\mathrm{C} 1$, and the alternative pathway by the C3, in an enzyme cascade order (26). Coating of bacteria or virus infected cells with fragments of the components $\mathrm{C} 3$ and $\mathrm{C} 4$ lead to their ingestion by phagocytic cells that possess receptors for these opsonins (27). Apart from its direct antimicrobial effects, complement maintains Igs in soluble form by limiting the formation of harmful immune complexes and Ig precipitation.

Thus, while sharing numerous similarities with other species, the bovine innate immune system possesses some unique features that likely together with the distinct anatomy of ruminants contributes to their resistance (rumen) or increased susceptibility to bacterial and metabolic diseases.

\section{ADAPTIVE IMMUNE RESPONSE}

Bovine plasma cells produce at least five heavy chain classes (IgM, IgG, IgA, IgD and IgE), with three IgG subclasses (IgG1, IgG2 and IgG3), two IgM subclasses (IgM1 and IgM2) and two light chain types ( $\lambda$ and $\kappa)$ (28). While the functions of IgM, IgA, IgG1 and IgG2 molecules are well-studied, those of IgG3 and IgD have not been evaluated in depth due to their later discovery. In contrast to many other animals, cattle only express a limited number of variable Ig gene segments, and it is thought that Ig diversity is achieved via frequent recombinations and endogenous mutations in the CDR3 region (29). Additionally, an unusually long CDR3 results in "microfolds" allowing bovine Igs to bind antigens that would otherwise be inaccessible (30). Immunoglobulin functions include neutralizing antibody $(\mathrm{Ab}$, complement activation, Fc receptor-mediated phagocytosis, and Ab-dependent cellular cytotoxicity. Differences exist between different cattle breeds in relation to immunoglobulin quantities (31). IgG1 and IgG2 are highly important, with IgG1 being the most abundant in cow colostrum. IgG is important for virus and toxin neutralization and bacterial agglutination and opsonization. In cattle, IgG1 is known to be a less potent opsonin than IgG2 (32). IgM is a pentameric molecule important for bacterial agglutination, complement fixation and opsonization and is more restricted to intravascular spaces because of its size. IgA is predominant in many secretions, but present in low quantities in bovine serum (31). It is important for antiviral defense in the upper respiratory and gastrointestinal tracts.

Although methods for analysis of the clonal composition of $\mathrm{T}$ cells have been used extensively to gain a better understanding of the mechanisms of $\mathrm{T}$ cell responses in humans and mice, this knowledge is more limited for bovine $\mathrm{T}$ cells (33). The antigen specificity of CD4+ and CD8+ T cells is determined by the $\alpha \beta \mathrm{T}$ cell receptor, which binds to peptides in association with $\mathrm{MHC}$ class II and class I molecules, respectively (34). Most CD4+ T lymphocytes function to promote cell-mediated immunity and Ab production, while certain CD4+ Th lymphocytes are capable of lysing appropriately sensitized target cells. Most CD8+ T lymphocytes function as effector cells of direct target cell lysis and are known as classical cytotoxic T lymphocytes (CTL), but some may function as non-lytic suppressor cells $(35,36)$. Major $\alpha / \beta \mathrm{T}$ cell subsets found in other species were also identified in cattle. They include: T killer (CD8+), T helper (CD4+, Th1, Th2 ad Th17) and T regulatory (CD4+/CD8+CD25+) cells, and their functions have been studied in relation to some infections and post-vaccine immune responses $(37,38)$. Earlier data suggested that cytokine-mediated regulation of Th1/Th2 cell responses in bovids may be more complex and distinct from that observed in mice (39). Specifically, parasite-specific bovine Th cells produce IL4 and IFN $\gamma$, while IL2 and IL10 expression is not restricted to IFN $\gamma$ or IL4-producing cells, respectively. Also, IL4/IL10 and IL12 do not selectively exert their suppressive or stimulatory effects on Th1-like cells. Nevertheless, some studies demonstrated that development and maintenance of a Th1 IFN $\gamma$ response can be associated with a greater control of some infections (M. bovis) (40).

Besides their critical role in shaping B cell responses, several studies emphasize the importance of bovine $\mathrm{T}$ cell responses that contribute to clearance of infections (for example Cryptosporidium parvum) in the absence of humoral/Ig responses (41). Of interest, memory CD4+, CD8+, and $\gamma \delta \mathrm{T}$ cells are detected in calves in the presence of maternal Abs even in the absence of an active $\mathrm{Ab}$ response (38). 
Thus, the bovine adaptive immune responses are driven by a combination of common and unique aspects that need to be considered when developing age- and herd-specific preventative and therapeutic strategies.

\section{MUCOSAL IMMUNE SYSTEM}

The mucosa includes 4 distinct major components: (1) microbiome; (2) mucous layer, (3) mucosal epithelial barrier, and (4) immune cells of the mucosa-associated lymphoid tissues [MALT; lamina propria (LP), Peyer's patches (PP) in the gut and diffuse mucosal lymphocytes] $(42,43)$. The microbiome is critical for immune development of young calves as well as immune defense and health maintenance of cattle of all ages (43). While the role of the rumen in mucosal immunity has not been yet clarified, it is established that bacterial richness and diversity were the highest compared with all other gut sections $(42,44)$. Bile acids (BA) in the small intestine represent another important mechanism of intestinal defense (45) and the gut microbiota plays a role in their metabolism. Bile acids inactivate enveloped viruses and some enteropathogenic bacteria; however, enterococci and Bacteroides spp. can degrade them, while commensal bacteria metabolize BA in the colon (45). The mucous barrier consists of the mucous and mucins (secreted by Goblet cells), antimicrobial peptides (AMPs; defensins, REGIII, lactoferricin), as well as IgG and secretory IgA (transported from LP). Epithelial cells (ECs; enterocytes in the gut and ciliated ECs in the lung) line the gastrointestinal (GIT), reproductive (RepT), urinary (UT) and respiratory (RespT) tracts and express tight junction proteins forming the mucosal epithelium (ME). If the tight junctions break down, the epithelium becomes leaky leading to systemic inflammation. This condition is best known as "leaky gut" but can be observed in RepT and RespT. Besides providing mechanical segregation, the ME functions include secretion and absorption (in the gut), fetal development (in the uterus), oxygen exchange and clearance of foreign substances and pathogens (in the RespT), and innate immune response. Bovine ECs express the whole repertoire of TLRs $(1-10,46)$. Based on luminal stimuli, ECs can produce pro-inflammatory (IL1 $\alpha$, IL8, and TNF $\alpha$ ) or regulatory cytokines (IL10 and TGF $\beta$ ) $(42,47)$. The microbial components stimulate ME to produce serum amyloid $\mathrm{A}$, which stimulates DCs to activate other important mucosal Treg cell, Th17 cells that produce high amounts of IL17A and ILnd moderate amounts of IL22 and $\operatorname{IFN} \gamma(48,49)$. The latter are critical for mucosal protection and repair as well as for defensin production (e.g., REGIII $\gamma$ and REGIII $\beta$ ) (42).

While the information regarding rumen-associated lymphoid tissues is limited, rumen fluid leukocyte populations (including monocytes, $\mathrm{T}$ and $\mathrm{B}$ cells) are likely to play a significant role in regulation of cattle immune and biochemical parameters (50). So, CD45 gene expression in rumen fluids (indicative of leukocyte infiltration) negatively correlated with ruminal $\mathrm{pH}$, while the frequencies of B cells (as well as numbers of total IgG and $\operatorname{IgM}$ ) were negatively affected by ruminal $\mathrm{pH}$ and high concentrations of volatile fatty acids. Additionally, rumen health disorders (e.g. subacute ruminal acidosis), were shown to cause ruminal dysbiosis breaching the epithelial barrier and leading to inflammation (51).

Organized MALT - the induction site of mucosal immunity is widely distributed in the mucosa throughout the body allowing for antigen sampling from mucosal surfaces. It is composed of gut-associated lymphoid tissues (GALT), bronchus-associated lymphoid tissues (BALT), nasal (nasopharynx)-associated lymphoid tissues (NALT) and lymphoid tissues in the RepT, UT, mammary gland(s), lacrimal glands and salivary glands. These lymphocyte aggregates or follicles (also known as lymphoid follicles [LF] or PP in the gut) of B cells, T cells, and DCs and macrophages antigen presenting cells (APCs) are covered by specialized epithelial cells called dome or $M$ cells [found in BALT, GALT and in uterus] (52-54). The GALT is the largest lymphoid organ and the largest body surface in contact with a great diversity of food and microbial antigens. The M cells (present in MALT) pinocytose antigens and transport them across the ME, where they are processed by APCs and presented to $\mathrm{T}$ and $\mathrm{B}$ lymphocytes $(54,55)$. Then, antigenstimulated mature $\mathrm{T}$ cells and $\mathrm{B}$ cells act together to produce IgA. Some of them express special molecules in their membranes (homing receptors) and leave the submucosal lymphoid tissue and enter the bloodstream; they can further exit the bloodstream through high endothelial venules and translocate to LP. Ultimately, this local stimulation results in memory $\mathrm{T}$ and $\mathrm{B}$ cells that can migrate to the nearby and distant mucosal and other tissues, which is known as "common mucosal immune system" (42). A part of this "common mucosal immune system" the bovine entero-mammary link (or gut-mammary axis) is critical for neonatal calf survival and health (45). This endogenous entero-mammary pathway not only allows lymphocytes to traffic to the mammary gland, but also transports some bacterial components during lactation in the cow (56).

A better understanding of the mucosal immune response and systematic evaluation of bovine vaccine efficacy based on immunization route will help to identify the pathogens that may be cleared more efficiently with mucosal $v$ s. parenteral vaccines.

\section{SYSTEMIC IMMUNITY}

While the mucosal immune responses are more important for the clearance of most pathogens (especially enteric and respiratory), for a number of viral and bacterial agents associated with systemic, chronic or lymphoid organ infections, protective immunity and pathogen clearance are unachievable without a robust systemic immune response. These pathogens include (but are not limited to): Staphylococcus aureus, FMDV, BRSV, Haemophilus somnus and Mycoplasma bovis (57-60). Studies of immune responses to these pathogens identified some commonalities as well as distinct systemic responses. IgG1 and IgG2 Ab responses predominant in serum (in contrast to IgA in various mucosal 
secretions), as well as potent and balanced CD4+ and CD8+ T cell and IFN type I responses in systemic immune organs and blood, were associated with improved protection. Another pathogen common in cattle, Leptospira interrogans (L. interrogans) enters the hosts through chafed skin or mucosa and then is disseminated in blood, potentially leading to renal infection (61). At the disease onset, symptoms are non-specific leading to it being underdiagnosed and poorly controlled by vaccines. Intraperitoneal priming with a TLR2/NOD2 agonist was shown to induce a sustained protective systemic innate immune response characterized by enhanced pro-inflammatory cytokine, chemokine and nitric oxide production by macrophages independent of the presence of B and T cells (62).

While most recent data suggest the importance of the systemic immune responses in some infections, it is also evident that tissue-specific immune responses may play important roles specific for each pathogen which requires further evaluation.

\section{PATHOGENS ASSOCIATED WITH IMMUNOPATHOLOGY}

Several important bovine pathogens have evolved mechanisms allowing them to subvert the immune system and establish persistent infections. These mechanisms are diverse and not completely understood which makes the use of classical vaccination and other approaches to control these pathogens challenging and sometimes impossible. Below we will summarize the strategies used by some of these pathogens to suppress host immune responses, as well as the mechanisms they use to modify themselves or their location in the host to block the recognition by the host immune system.

BVDV has evolved unique mechanisms to establish persistent infection characterized by immune tolerance of the noncytopathogenic (ncp) variant (63). Due to its immunosuppressive effects on both the innate and adaptive immune systems, BVDV acts as a major predisposing factor for BRD. Interestingly, ncpBVDV suppresses production of IFN type I and proinflammatory cytokines in bovine alveolar macrophages whereas its cytopathogenic counterpart triggers this response. This suppression leads to the decreased phagocytic activity. Additionally, cells infected with ncpBVDV are also resistant to induction of interferon by dsRNA, a potent inducer of IFN type I. Further, in vitro infection of monocyte-derived macrophages with both cytopathic and ncpBVDV suppresses responsiveness to TLR2, TLR3, TLR4 but not TLR7 ligands (64). Because IFN $\alpha$ production is critical for initiation of the adaptive immune response, its inactivation by ncpBVBDV may represent the key mechanism affecting both innate and adaptive immunity. Similar to in vitro findings, in vivo BVDV infection also modulates the capacity of monocytes and macrophages to respond via TLR4 (65).

Another example of immunopathological response associated with bovine viral pathogens is bovine leukemia virus (BLV). It is characterized by increased numbers of CD4+CD25+Foxp3+ Treg cells that produce higher levels of TGF $\beta$ resulting in reduced production of IFN $\gamma$ and TNF $\alpha$ by CD4+ T cells and impaired NK cell function $(12,66)$. These immunological impairments lead to increased susceptibility to opportunistic infections. Additionally, the production of antiviral cytokines (including IFN $\gamma$, IL2 and IL12) by lymphocytes and their proliferative ability in response to BLV was also significantly reduced in cattle with persistent lymphocytosis (67). In contrast, it was demonstrated that the protective Th1 response against Mycobacterium avium subsides later in the course of the infection, while the non-protective Th2 response becomes prominent. Recent data demonstrated that $\mathrm{T}$ cell unresponsiveness, rather than Treg activity, is driving this Th1-to-Th2 immune shift (68).

Recent studies have improved our understanding of exhaustion and dysfunction of antigen-specific $\mathrm{T}$ cells in chronic infectious diseases of cattle. They demonstrated that up-regulation of surface expression of immunoinhibitory receptors, such as programmed death 1 (PD-1), lymphocyte activation gene 3 (LAG-3), T-cell immunoglobulin and mucin domain-containing protein 3 (Tim-3) and cytotoxic $\mathrm{T}$ lymphocyte antigen 4 (CTLA-4) by bovine $\mathrm{T}$ cells play a critical role in immune exhaustion and disease progression in the case of BLV infection, Johne's disease (caused by Mycobacterium avium) and bovine anaplasmosis (11, 69-72).

Of interest, while some FMDV infected ruminants can clear the virus within 1-2 weeks, some remain persistently infected for up to 3 years (73). This dichotomy and how FMDV evades cytotoxic $\mathrm{T}$ cell responses are not completely understood. Thus, further studies to understand this and to determine how the carrier status and FMDV-associated immune modulation can affect cattle susceptibility to other pathogens are warranted.

These pathogens can further compromise cattle health predisposing them to secondary infections due to immune suppression. Strict biosecurity measures (whenever possible) combined with vaccines and nutritional interventions need to be implemented to reduce prevalence of these pathogens.

\section{IMMUNE SYSTEM AND MICROBIOME}

As in most other mammals, bovine fecal microbiota is dominated by the 5 following phyla: Firmicutes (the most prevalent, 63.84\%-81.90\%), Bacteroidetes (8.36\%-23.93\%), Proteobacteria (3.72\%-9.75\%), Fusobacteria (0.76\%-5.67\%), and Actinobacteria (1.02\%-2.35\%) (74). Similar to findings from other species, fecal microbial diversity in cattle is associated with diet, age, disease status and growth rates, and increased abundance of Faecalibacterium spp. is suggested to promote health and growth (74).

The development and establishment of the gut microbiome is a dynamic process that can be influenced by several internal and external factors. Internal (=host-related) factors include functional maturity of the gut and immune system, biliary secretions and repertoire of bacterial mucosal receptors (75, 76). The list of external factors is broader including everything in the calf environment including the calf nutritional status, vaginal, fecal and milk microbial composition of the cow, 
antibiotic use, etc. (43). As the calf grows, the gut bacterial composition develops quickly culminating in a "climax" community maintaining the anaerobic environment (77).

The rumen - an anaerobic and methanogenic forestomach houses an abundant and complex microbiota $\left(\sim 10^{10}-10^{11}\right.$ cells/ $\mathrm{ml}$ and over 200 species) responsible for the remarkable ability of cattle to transform indigestible plant mass into essential nutrients (78). Bacteria are the most abundant microbes in the rumen and their composition is determined by a number of factors including the diet, energy requirements, and resistance to certain metabolic byproducts toxic to some species. Several studies demonstrated that rumen bacteria of animals fed high forage or high grain diets mainly consisted of Gram negative or Gram positive bacteria (including Lactobacillus), respectively, while increased proportion of corn silage resulted in increased Prevotella and decreased protozoal abundance $(79,80)$. Numerous studies demonstrated that a large microbial component remains uncultured, while fundamental diet-driven differences were noted in the glycoside hydrolase content (81). Another recent study emphasized the importance of the ruminal microbiota and suggested that different breeds of dairy cows have different metabolic, immunological and performance traits (82).

Central (e.g., bone marrow and thymus) and peripheral (e.g., lymph nodes, spleen, and MALT) organs of the calf immune system develop in prenatal and postnatal periods with maternal and calf microbiota playing a significant role during both periods $(43,83)$. In the first $24-36$ hours of life, calf gut permeability decreases significantly due to the increase in expression of the tight junction (TJ) proteins (occludin, claudins, zonula occludens, and junctional adhesion molecules). Although, the exact mechanisms are not known, interactions between the ME and some bacteria (e.g., Lactobacillus spp and Bifidobacterium spp) or bacterial metabolites upregulates TJ expression promoting intestinal barrier integrity (84). The production of mucus - another immune defense barrier - is stimulated by the presence of commensal bacteria (85). As summarized by Gomez and colleagues, other evidence accumulated in various animal models indicates that commensal microbiota stimulates enterocyte turnover and metabolic activity, enhances production of AMPs by enterocytes and Paneth cells and secretory IgA production (43). Low levels of secretory IgAs are associated with bacterial expansion leading to systemic inflammation and/or diarrhea (86). While over-proliferation of Enterobacteriaceae spp has been associated with diarrhea in calves (87), the role of IgA secretion in this condition is unknown and warrants further investigation. Further, expression of TLR2 and TLR6 is downregulated with increasing age in calves which is associated with increased abundance of digesta and tissue-associated total and lactic acid bacteria (88). Expression of TLRs in the gut of calves is also influenced by gut region, which in turn can be due to regional variations in the density of microbial communities (88). It is also possible that the colonization of the calf gut by Lactobacillus spp and Bifidobacterium spp promotes a regulatory immune response (increased IL10 secretion) thereby avoiding exacerbated inflammatory responses to commensal microbiota (89). While there are now comparative studies evaluating systemic immune responses in germ-free and conventional calves, there is growing associative evidence that the microbiome-associated alterations in the immune function are observed in the gut and systemically. For example, the stress of comingling, transportation, weaning and other abrupt dietary changes also alter microbial composition in the gut which may lead to intestinal dysbiosis. Dysbiosis and the associated immune alteration can in turn predispose calves to various infectious diseases, including Johne's disease (paratuberculosis) (90). Another example of systemic immune modulation by gut bacteria is from a study where lysozyme, lactic acid and glycopeptide (isolated from Lactobacillus spp) treatment decreased numbers of $\mathrm{T}$ helper, but not CD8+ cells, numbers of CD25+, CD38+, as well as CD69+ and CD95+ cells and increased frequencies of IL2 receptor expressing cells in cow blood. Those changes were associated with a significant elevation of somatic cell counts and decreased numbers of pathogenic bacteria in the milk of the treated cows (91).

These data suggest that intestinal dysbiosis and the associated infectious or metabolic diseases in dairy cattle may represent a significant challenge that needs to be addressed via nutritional adjustments or probiotic treatments.

\section{IMMUNE SYSTEM AND NUTRITION}

Dairy cow nutritional status and metabolism of specific nutrients are critical for adequate immune and other cell functions. The effects of nutrition may be direct through nutrients or indirect via metabolites. A majority of health problems in dairy cattle occur around parturition due to the hormonal shifts and the need of adaption to the increased nutrient demands for lactation resulting in negative energy balance. Diet-associated uncontrolled inflammation is considered to be a major contributing factor to several metabolic diseases common in dairy cattle including mastitis, retained placenta, metritis, displaced abomasum, and ketosis (92). Previous studies demonstrated that over- or undernourished cows were more susceptible to various infectious diseases compared to those with adequate nutritional status in periparturient period (93). Somewhat conflicting evidence of the associations between transient dietary restrictions, neutrophil function reduction and various inflammatory diseases in postpartum dairy cows is discussed by Sordillo (92). Provision of appropriate antioxidants including omega-3 polyunsaturated fatty acids, conjugated linoleic acid and vitamin $\mathrm{D}$ promotes anti-inflammatory responses (94). Deficiencies in certain micronutrients (vitamins and trace elements) are associated with an increased incidence of mastitis, retained placenta, and metritis (95). The immunomodulatory and antioxidant effects of various macro- and micronutrients that influence the incidence of health disorders in dairy cattle have been discussed in detail in several previous reviews and are briefly summarized in Table $\mathbf{1}$ (109-113). These immunological and metabolic disturbances in lactating cows as well as dairy calf feeding practices may result is suboptimal nutrition and immune protection of neonatal calves. 
TABLE 1 | Role of macro- and micronutrients in the immune function of cattle.

\begin{tabular}{|c|c|c|}
\hline Nutrient & Role in immunity & References \\
\hline Fat/energy & $\begin{array}{l}\text { Regulates cell mediated immunity and Ab response. Fat-derived fatty acid composition of immune cells affects phagocytosis, } T \text { cell } \\
\text { signaling and antigen presentation capability }\end{array}$ & $(96,97)$ \\
\hline Protein & $\begin{array}{l}\text { Protein/amino acids are required for proliferation and maturity of immune cells. Specific amino acids (e.g. tryptophan, arginine, glutamine) } \\
\text { are required for systemic and gut immune function }\end{array}$ & (98) \\
\hline Glucose & Up-regulation of cell proliferation, differentiation, survival, chemotaxis, phagocytosis & (99) \\
\hline Glutamine & Up-regulation of cytokine and reactive oxygen metabolite (ROM) production, cell division, phagocytosis, CD4 T cell proliferation & $(100)$ \\
\hline Tryptophan & Activation and maintenance of the immune response & $(101)$ \\
\hline Fatty acids & $\begin{array}{l}\text { Down-regulation of IgM secretion, cytokine production, cell viability, phagocytosis, diapedesis, antigen presentation. Up-regulation of } \\
\text { oxidative burst, necrosis, phagocytosis, cytokine and ROM production, TLR signaling }\end{array}$ & (96) \\
\hline Selenium & Maintenance of the antioxidant system, enhancement of neutrophil function and neutrophil and macrophage migration & $(102,103)$ \\
\hline Zinc & $\begin{array}{l}\text { Overall immune function, antioxidant activity [integral part of superoxide dismutase (SOD)], epithelial barrier integrity, nucleic acid and } \\
\text { protein synthesis, cell division }\end{array}$ & $(98,103)$ \\
\hline Copper & Overall immune function, antioxidant activity [integral part of superoxide dismutase (SOD)], enhancement of interferon production & $(98,104)$ \\
\hline Iron & Antioxidant defense (essential component of catalase), energy and protein metabolism, oxidation-reduction reactions & $(105)$ \\
\hline Manganese & Overall immune function, antioxidant protection (integral part of SOD), carbohydrate and lipid metabolism & $(106)$ \\
\hline Chromium & $\begin{array}{l}\text { Regulation of cell-mediated and humoral immune responses, upregulation of blastogenic response, enhancement of cytokine (IL2, IFN, } \\
\text { and TNF } \alpha \text { ) production by mononuclear cells, Ab production }\end{array}$ & (98) \\
\hline $\begin{array}{l}\text { Vitamin A, } \beta \text { - } \\
\text { carotene }\end{array}$ & Overall immune function, upregulation of lymphocyte proliferation & $(103)$ \\
\hline Vitamin B & Antioxidant defense, upregulation of lymphocyte proliferation & (98) \\
\hline Vitamin D & Antioxidant defense, down-regulation of inflammation & $(107)$ \\
\hline Vitamin C & Antioxidant defense, down-regulation of inflammation & (108) \\
\hline Vitamin E & $\begin{array}{l}\text { Lipid soluble antioxidant, enhancement of neutrophil function, increase of production of IL1 and major histocompatibility (MHC) class II } \\
\text { antigen expression }\end{array}$ & $(102,103)$ \\
\hline
\end{tabular}

\section{IMMUNE FUNCTION IN PREGNANCY AND EARLY PARTURITION}

The immune mechanisms discussed above play critical roles at the maternal-fetal interface and in the neonatal periods. Importantly, pregnancy hormones induce changes in immune cell populations and functions to promote immune tolerance, reduce expression of major histocompatability proteins by the trophoblast, tissue remodeling, and angiogenesis (114). In early pregnancy in cattle, complex hormonal and immune shifts occur: the conceptus blocks the luteal regression to maintain progesterone production that prevents the fetus from destruction by the maternal immune system. Recent studies evaluated immune regulation of the maternal uterus, peripheral blood mononuclear leukocytes and corpus luteum induced by IFN $\tau$, the primary pregnancy recognition signal in cattle (115). Frequencies of endometrial NK cells, CD8+ T cells, macrophages and DCs as well as IL15 and IL10 cytokine levels are also markedly increased in early pregnancy (114). The findings suggested that the bovine embryo triggers an anti-inflammatory response in immune and epithelial cells. Furthermore, expression of indoleamine 2,3 dioxygenase (IDO, converts tryptophan to kynurenine altering immune function) is increased in the first trimester in dairy heifers (114). IDO activates the aryl hydrocarbon receptor (abundant in bovine uterus), thus, inducing downstream tolerogenic mediators. Pregnancy is also associated with increased expression of proteins inhibiting immune activation and inducing lymphocyte tolerance, including programed cell death ligand-1, lymphocyte activation gene-3, and cytotoxic T-lymphocyte associated protein4. There is also evidence of enhanced TLR expression and macrophage recruitment and activation in the cow endometrium early in pregnancy; however, the reasons for the latter are not fully understood (116). Besides IFN $\tau$, placental lactogen, pregnancy-associated proteins, prostaglandin E2, nonclassical MHC class I, GATA transcription factors, prolactinrelated protein, Cox-2 and IL6 are secreted by the conceptus in early pregnancy. It was suggested that IFN $\tau$ (and other conceptus signaling factors, Figure 1) may be involved in maternal systemic immune regulation through modifying peripheral blood mononuclear leukocytes, platelets and cell-free embryonal DNA by the lymph circulation and blood circulation in the bovine (Figure 1). Besides its anti-luteolytic function, IFN $\tau$ also functions to promote uterine receptivity and embryo development. It enhances the expression of IFN-stimulated genes (including TNF $\alpha$ and MCP1) in the endometrial tissue of cattle (117). Maternal immune responses during embryo elongation in cattle include increased numbers of monocytes and DCs in the endometrial stroma, while $\mathrm{MCP} 1 / 2$ serve as a potent chemotactic factor for monocytes and DCs (117). Further, a subpopulation (M2) of activated macrophages and several cytokines [including IFN $\gamma$, IL4, and Leukemia inhibitory factor (LIF)] act to decrease the activation of anti-conceptus immune responses (118-120). These early modifications and consistently high levels of progesterone (P4, Figure 1) result in an immune balance shift toward Th2 and its maintenance until periparturient period $(121,122)$. At parturition, however, the ratio of Th1/Th2 should increase a rapid transition from tolerance for the fetus (high Th2) to protection against infectious agents (high Th1) (123). There is also limited evidence of partial immune suppression in periparturient cows showing that frequencies of peripheral blood CD4+, CD8+ and $\gamma \delta \mathrm{T}$ cells and IFN $\gamma$ decline, while the numbers of CD25+ T cells increase (116). B cell clonal expansion and antibody production also decrease reaching nadir around parturition (124). The week prior to and immediately after 


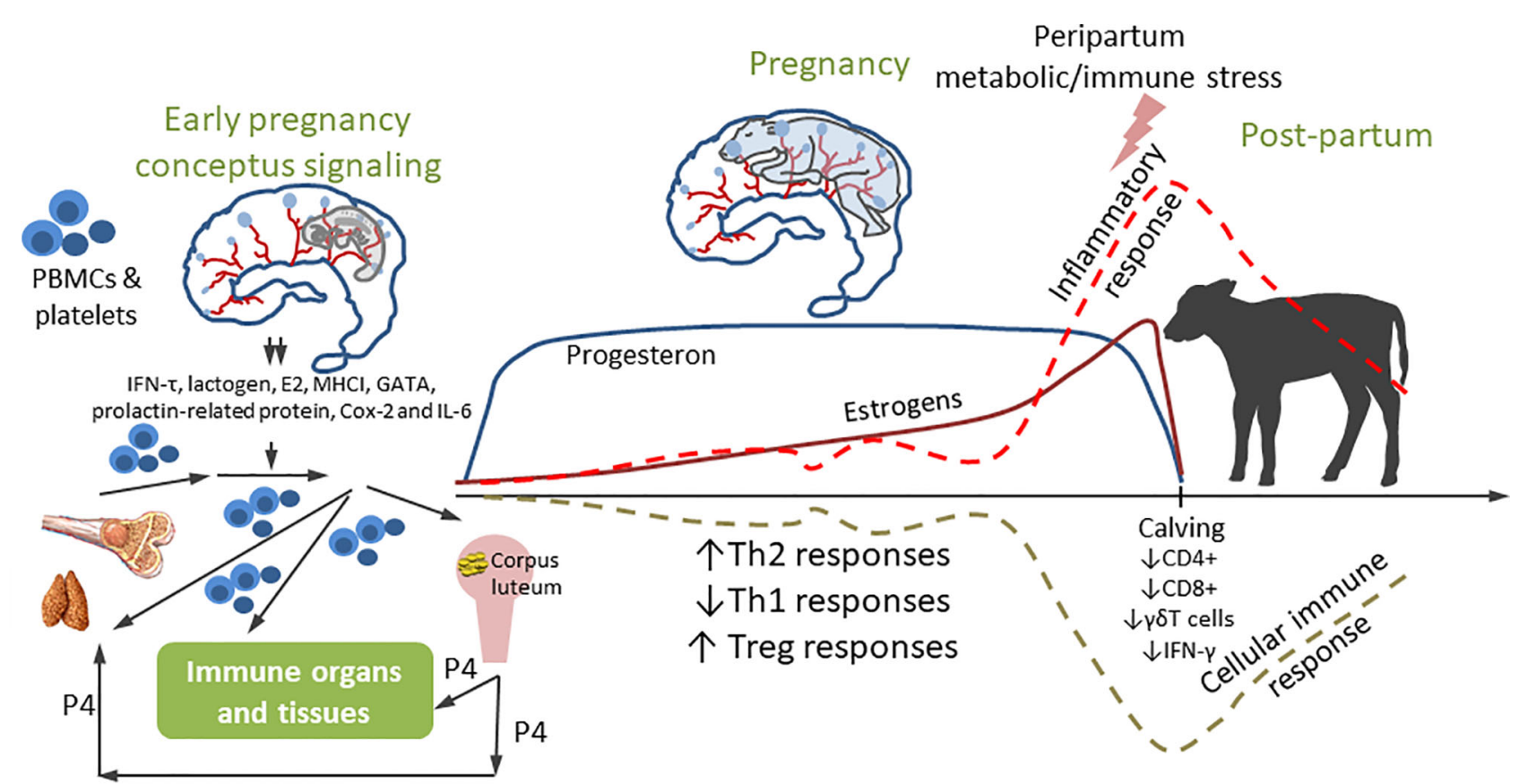

P4

FIGURE 1 | Immune modulation during pregnancy. Early conceptus signaling modulates local and systemic immunity. The peripheral blood mononuclear cells (PBMC), platelets and cell-free DNA from bone marrow/thymus modulated by high level of P4 from corpus luteum enter blood circulation. Then, the PBMC, platelets and cell-free DNA while migrating through blood circulation to endometria, are controlled by IFNT and other conceptus immune factors. Then the functionally changed PBMC, platelets and cell-free DNA re-enter blood/lymph circulation and traffic to effector cells affecting the function of the immune organs and non-immune organs including ovary. This early signaling shifts immune environment to Th2 to maintain the pregnancy. Inflammatory responses sharply increase, and cellular immune function is down-regulated around parturition.

parturition is also associated with neutrophilia, eosinopenia, lymphocytopenia and monocytosis. Additionally, cows show a decrease in phagocytosis and oxidative burst activity (125). These findings suggest that there is another immunological shift occurring before calving. Heyland et al. (126) hypothesized that around parturition multiple external insults can induce a systemic inflammatory response capable of attenuating the cellular immune response (126) (Figure 1). Further, some findings suggest that release of fetal membranes can be an immune/ hormone-mediated process because increased incidence of retained placenta (RP) is observed in cows sharing MHCI antigen specificity with their calves (127). It is well established that daily food intake decreases $(\sim 30 \%)$ as calving approaches (128), which coincides with increases in levels of proinflammatory cytokines (50). Dairy cows do not consume enough nutrients to meet the increased demand to support lactation which leads to a negative energy balance (NEB). NEB in turn leads to suppressed immune function or poorly controlled inflammation which may promote uterine diseases and other metabolic diseases including milk fever, ketosis, and displacement of the abomasum (113).

Thus, the immune function and its regulation during pregnancy, from the conception and through parturition are very complex and dynamic with selective suppression and upregulation of distinct immune responses. These aspects have to be carefully considered in vaccination approaches to maintain optimal health of periparturient cows and neonatal calves. Other disease controlling strategies should also be tailored to the stage of production of dairy cows.

\section{THE BOVINE MAMMARY GLAND IMMUNE DEFENSES}

The ability of lactating cows to resist invading pathogens (bacterial) and clear them is primarily dependent on the function of the mammary gland (MG) immune system, although systemic immunity also plays a role. Also, calves are born agammaglobulinemic (because there is no transplacental transport of Igs in cattle) and rely fully on consumption of colostrum and milk to ensure adequate passive immunity (83).

The bovine MG is equipped with a non-immune anatomical barrier, and a plethora of immune mechanisms, including coordinated action of innate and adaptive immune responses (129). Detailed reviews by Rainard (130), Ezzat Alnakip (131) and Sordillo (132) summarized the immunobiology of the bovine MG and the mechanisms of its immune defense that include common cellular and soluble immune components discussed earlier as well as some unique biochemical, mechanical and immune factors (Figure 2). Among the latter is the teat canal 


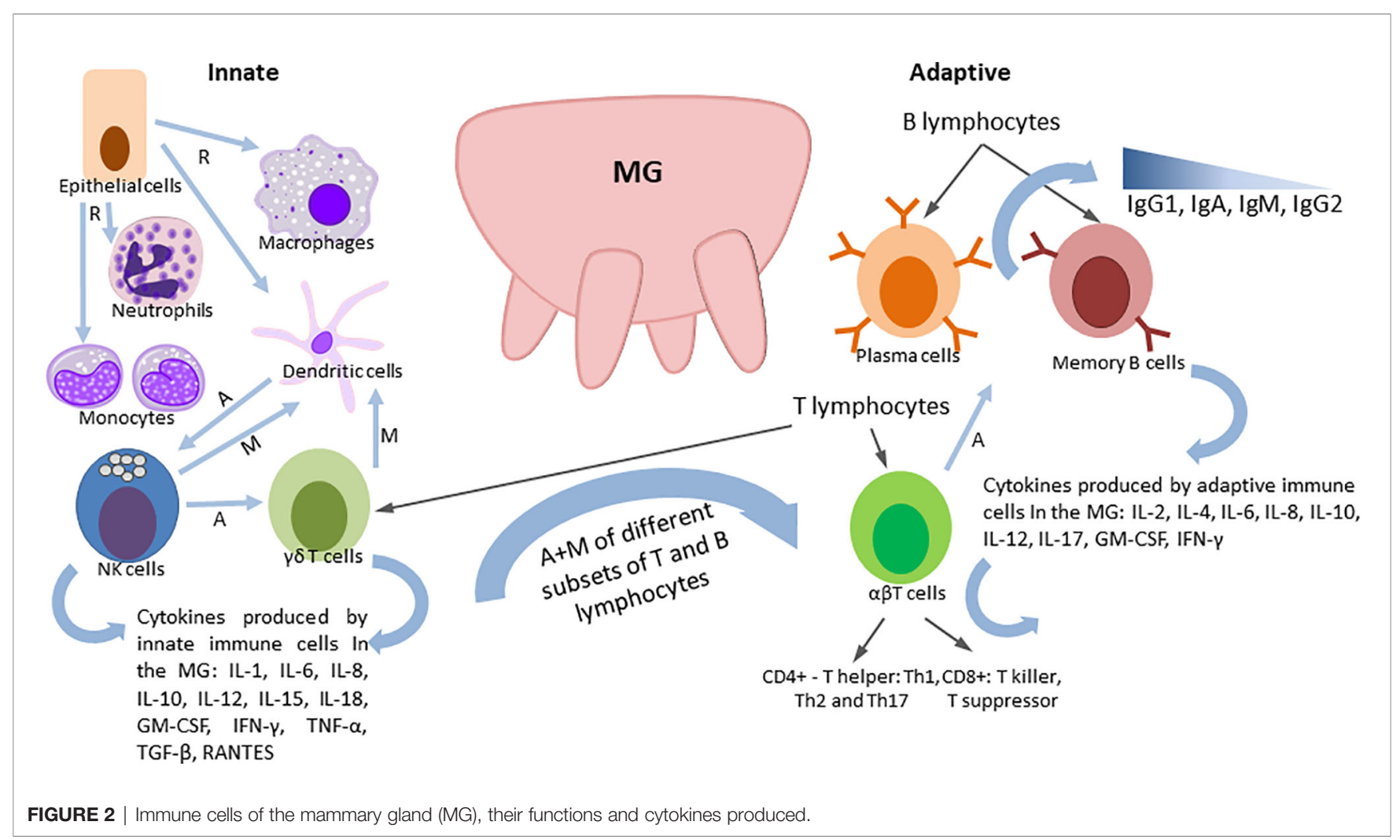

barrier with the following defense factors: contraction of the teat sphincter muscles to block bacterial penetration; bacteriostatic activity of keratin and Furstenberg rosette densely populated with leukocytes. Lactoferrin, a unique soluble secretion of the MG, is one of the best-characterized antimicrobial proteins and is the most common iron-binding protein that greatly reduces soluble ferric iron available to multiplying bacteria. Transferrin, lysozyme, lactoperoxidase and xanthine oxidase are also found in the milk of ruminants that play diverse roles in antibacterial defense (130). Major cell subsets with diverse immune functions, including epithelial cells, innate immune cells and $\mathrm{T}$ and $\mathrm{B}$ lymphocytes (Figure 2) are present in the MG. These cells interact directly or via soluble components to ensure optimal protection of the udder against invading bacteria and to provide passive protection to the calves with colostrum/milk.

Of all TLRs, TLR2 and TLR4 are of particular importance to MG defense because these receptors recognize PAMPs associated with gram-positive (peptidoglycans) and gram-negative (LPS) mastitis-causing pathogens, including Staphylococcus aureus, Streptococcus uberis, and Escherichia coli (133). While rapid and robust inflammatory immune responses can efficiently block or clear infection, their increased duration can lead to excessive tissue damage. This emphasizes the importance of the MG immune regulatory function that leads to the cessation of proinflammatory mediator synthesis and their catabolism. Cytokines IL4, IL10, and IL17 and oxylipids (regulating microvasculature and pro-/anti-inflammatory responses) play a critical role in the resolution of inflammation (19). The contribution of the complement system to the MG immune defense has been discussed in detail $(27,134)$. The classical pathway is not functional due to the lack of C1q, but the alternative pathway can operate, resulting in: 1) deposition of opsonic C3b and C3bi on bacteria, and generation of the proinflammatory fragment C5a (130). Natural Abs that cause bacterial opsonization are another component of innate humoral defenses. While generally, opsonic Abs belong to the IgG2 and IgM isotypes, the majority of the opsonic Ab in cow serum and milk of cows are IgM (130). Virus or bacteria specific immunoglobulins are the most important soluble humoral factors of the adaptive immune defense of the MG, linking the cellular and humoral immune system. Four classes of Igs (IgG1, IgG2, IgA, and IgM) influence MG antibacterial immune defense and play distinct roles depending on the lactation stage. IgG1 is the most abundant Ig class in bovine milk and colostrum (131, 135), while IgG2 levels increase substantially in inflammation (26) (Figure 2). Immunoglobulins in milk may be blood derived or produced in situ by antigen activated plasma cells, which traffic to the udder from the blood (136). Thus, unlike in monogastric animals, the dominant Ab (IgG1) in bovine colostrum/milk is actively transported from the peripheral blood (and not the gut), which allows for the use of parenteral vaccines in pregnant cows to boost serum IgG1 Abs with their subsequent transfer into milk and colostrum (137). The active IgG transport is mediated by neonatal Fc receptor, which is an intracellular, bidirectional and $\mathrm{pH}$-dependent process (138).

A depression of several immune functions that has been reported around parturition (in part regulated by increased level of blood glucocorticosteroids) manifests by a higher 
prevalence of clinical mastitis and other diseases during this period (139). An increase in IL2 secretion from late gestation to parturition emphasizes the immunological function (antiviral protection) of the bovine MG (140).

These unique aspects of bovine immune responses allow to provide protection to neonatal calves via parenteral maternal vaccination. Vaccination strategies should be further optimized to select optimal vaccination timing, vaccine types, doses and adjuvants.

\section{PASSIVE IMMUNE PROTECTION OF NEONATAL CALVES}

Dairy calves provide replacement animals critical for the future of the dairy operation. Passive immunity in calves is assessed by quantifying the levels of serum IgG or total protein during the first 7 days of age. Beef and dairy calves feeding is managed differently, beef calves are allowed to suckle, while dairy calves are separated from dams at birth or soon after, fed colostrum and placed on milk replacers. These differences in colostrum management may affect early immune development of calves. Whole blood immune transcriptome analyses demonstrated that there was a surge in pro-inflammatory cytokine expression in dairy calves, while sucking beef calves had increased expression of genes associated humoral immunity maturation by 7 days of age (141). Cow colostrum and milk provide key nutrients and passive protection to neonatal calves. Colostrum/milk components also include casein, lactoferrin, whey proteins and lactoperoxidase as well epithelial and immune cells (macrophages, $\mathrm{T}$ and $\mathrm{B}$ lymphocytes). These cells cross the neonatal intestinal barrier and populate peripheral and central lymphoid tissues promoting the calf immune development (142). Bovine colostrum also contains potent bioactive components that promote growth (EGF and TGF $\beta$ ) and counteract pathogens (proinflammatory cytokines: IL1b, IL6, TNFa and IFN $\alpha$ ), enhance lymphocyte function and promote maturation of the neonatal intestinal immune system (143). Cytokine concentrations in bovine colostrum are much higher than in mature milk, which contribute to the production of secretory IgA as well as Th1 and Th2 responses (144). Colostrum also contains maternal immunoglobulins and immunomodulatory factors that suppress development of active immunity (145). Thus, in addition to nutrition, mammary gland secretions play at least two more important roles: generation of tolerance to food antigens and commensal microbiota while promoting immune development and immune response to pathogens.

Because passive transfer of lactogenic soluble and cellular components from the mother to the calf prior to the gut closure (cessation of transport of macromolecules across the gut barrier) is the main means of anti-infectious protection immediately after birth, its failure (FPT) due to compromised maternal health, late calf feeding or feeding poor quality colostrum is associated with $>30 \%$ of mortality in pre-weaned calves (146). While low colostrum intake at birth is a risk factor for FPT for all calves, those from younger (especially primiparous) cows have lower serum Ig concentrations compared to those born to older cows, which also contributes to increased morbidity and mortality. Supplementation of commercial colostrum represents a viable strategy to alleviate the negative effects of the passive transfer failure (147). A majority of dairy calves are reared on pasteurized waste milk and milk replacers (148), and they are at higher risk suffering negative health sequalae due to FPT. Recent studies demonstrated that 2 vs 1 colostrum feedings after birth have resulted in decreased risk of FPT, reduced morbidity and improved growth rate $(149,150)$. Finally, the protection from the passive immunity transferred to calves peaks 1-2 days and then starts declining. Currently available commercial milk replacers are generally made of skim milk powder, vegetable or animal fat, buttermilk powder, whey protein, soy lecithin and vitamin-mineral premix (151). While their nutritional value has improved over the past decades, they remain deficient in immunological and growth/development promoting components leading to higher rates of infectious diseases.

These observations emphasize that the current feeding practices of pre-weaned dairy calves should be further optimized, including introduction of multiple colostrum feedings. Similarly, vaccination strategies of pregnant cows require in-depth evaluation to ensure optimal maternal health and passive protection of their offspring.

\section{EXISTING VACCINES AND THEIR EFFICACY}

Vaccination is a critical component of beef and dairy cattle health management. Effective vaccination programs require indepth knowledge of the circulating pathogens, their pathogenesis and immune responses in cattle, selection of the optimal timing and consideration of host factors such as age, health status, reproductive status, and external stressors.

Use of modified live-virus vaccines against respiratory pathogens in cattle upon feedlot arrival has been consistently recommended; however, emerging data suggest that it might not be optimal (152). This is because the stress associated with transportation leads to increased levels of cortisol and other pro-inflammatory factors that compromise vaccine efficacy. Thus, it is likely that giving the required vaccines prior to cattle shipment would be more beneficial; however, studies are needed to confirm this. Further, while benefits of maternal vaccination for improved calf health and survival are established (153-155); the optimal gestational age is not determined in cattle. Recent studies in pregnant swine demonstrated that second (but not first or third) trimester vaccination against porcine epidemic diarrhea virus resulted in optimal immune responses and health/survival outcomes in sows and their piglets (156).

Significant efforts were made in the last two decades to evaluate the efficacy of cattle vaccination against tuberculosis using human Bacille Calmette-Guérin (BCG, Mycobacterium bovis) vaccine, and the results have been promising (157-159). A meta-analysis of the effectiveness of vaccination of cattle with 
commercially available viral vaccines for mitigation of morbidity and mortality from BRDC has demonstrated variable results (160). While BHV-1 and BVDV vaccines decreased the risk of BRDC mortality/morbidity; experimental trials showed no differences between BRSV and PI3 vaccinated and control calves in reducing BRDC morbidity or mortality risk (160).

While many licensed vaccines and preventative therapeutic products for cattle are available (Table 2), there is still surprisingly limited, but emerging data on the efficiency of the existing vaccines for cattle in different production environments. Thus, the majority of vaccines, while showing some efficacy require further optimization and a better understanding of the bovine immune response and health status in different ages and production groups. Further, the optimal timing for vaccination of pregnant cows is not determined and coverage for some vaccines remains insufficient. Additionally, oral vaccination with attenuated pathogens may provide stronger and more lasting immunity. Finally, detailed examination of molecular mechanisms utilized by each pathogen (including immune suppressive mechanisms discussed below) and environmental factors is essential.

\section{ANTIMICROBIAL AND ANCILLARY THERAPIES IN CATTLE}

In cattle, the treatment of BRD and scours represents one of the major uses of antimicrobials $(173,174)$. Because numerous bacteria are involved into BRD development, its treatment normally includes an empirical antimicrobial therapy, including drugs from a wide variety of classes, with penicillins, tetracyclines, macrolides, and quinolones being most frequently used (175). While only a small proportion of animals may show clinical symptoms, treatment is generally applied to the whole herd contributing to improved pathogen control and animal survival (176). However, such an (metaphylactic) approach may result in contamination of the food chain and the environment with antimicrobial resistance (AMR) factors (bacteria and genes) (177). Early detection and treatment of diseased animals allows use of substantially lower doses of antimicrobial drugs, thus reducing the AMR concerns; however, methods and tools for reliable early detection have not been developed (177). Nonetheless in the age of personalized medicine for humans and pets, it is anticipated that such technologies will be forthcoming for livestock as well.

Oxytetracycline and sulfachloropyridiazine administered parenterally and amoxicillin, chlortetracycline, neomycin, oxytetracycline, streptomycin, sulfachloropyridazine, sulfamethazine, and tetracycline administered orally have been approved by the US Food and Drug Administration (FDA) for the treatment of $E$. coli enteritis (colibacillosis) but the evidence of their efficacy is scarce or absent (174). Optimal therapy of cryptosporidial infection in calves remains to be identified with current data suggesting that halofuginone, azithromycin, and lasalocid can be effective (177). The initial observations of increased incidence of diarrhea, reduced growth and malabsorption in healthy calves treated with penicillin, chloramphenicol, and neomycin (174), combined with concerns regarding development of antimicrobial resistance, suggested that use of antimicrobials should be conservative to minimize potential negative effects on animal or human health (178). This and the lack of highly efficient vaccines against most major bovine pathogens has prompted investigations of ancillary and comprehensive strategies to improve and maintain cattle health.

Additional treatments directed at minimizing the effects of pathogens and improvement of non-specific resistance include: optimal nutrition and micronutrient supplementation (nutraceuticals, effects are discussed in the respective section), provision of sufficient amounts of colostrum/milk and feeding it in small doses for optimal digestion of scouring calves, analgesic and anti-inflammatory drugs (including meloxicam and nonsteroidal anti-inflammatory agents) to alleviate intestinal inflammation, pro- and pre-biotics and passive immune therapies.

It has become increasingly evident that a damaged intestine needs nutritional, immune and metabolic/growth factors present in fresh cow's milk to optimize intestinal repair. Thus, concurrent supplementation of milk and oral rehydration therapy (ORT) solutions resulted in improved intestinal morphology compared to ORT solutions alone (174).

Another emerging approach - aerosol vaccination using BCG vaccine to stimulate memory-like factors of the innate immune system (e.g. 'trained' non-specific immunity) was recently evaluated. This immunomodulatory strategy allowed to reduce disease burden in juvenile calves before their adaptive immune system has sufficiently matured (179).

Although not currently recommended as anti-infectious therapies, probiotics can be supplemented (with or without feed) to animals in an attempt to improve performance or increase resistance to enteric pathogens (180). The data on probiotic supplementation in cattle are extremely scarce and somewhat controversial. Lactic acid bacteria or Lactobacillus rhamnosus GG supplementation to calves did not decrease C. parvum or all cause diarrhea prevalence, respectively $(181,182)$; whereas E. coli Nissle 1917 (for 10-12 after birth) supplementation to calves resulted in a significant decrease in the number of calves developing diarrhea (183).

Chicken egg yolk IgY Abs derived from specific-microbe immunized chickens were efficient in protecting calves against several pathogens including $\mathrm{BCoV}, \mathrm{RV}, \mathrm{CoV}, \mathrm{BRSV}$, enterotoxigenic E. coli, salmonella (184-187). Several IgY Ab products are commercially available for calves. Furthermore, a blended treatment using pro-, prebiotics and IgY Abs was successful in reducing all-cause diarrhea in Holstein calves. Supplementation with a combination of Lactobacillus acidophilus, Bacillus subtilis, Bifidobacterium thermophilum, Enterococcus faecium, and Bifidobacterium longum, prebiotics (RFC-MOS, FOS), charcoal, and dried egg protein from hens hyperimmunized with $\mathrm{K} 99+E$. coli antigen, S. enterica var. Typhimurium and Dublin, CoV, and RV resulted in a decreased incidence of diarrhea during the first 3 weeks of life of calves (25.0\% vs. $51.1 \%$ in the control group) (188). 
TABLE 2 | USDA licensed antiviral and antibacterial vaccines and preventative therapeutic products for cattle.

\section{Vaccine/type \\ Autogenous vaccine, killed virus, autogenous bacterin}

Autogenous vaccine-autogenous bacterin

BHV-1 live vaccine; H. somnus, M. haemolytica, P. multocida, S. typhimurium bacterin toxoid

$\mathrm{BHV}$-1 - live vaccine; L. interrogans (Hardjo-Pomona) bacterin

BHV-1 live vaccine; L. interrogans (Pomona) bacterin

BHV-1, BVDV live vaccine; Campylobacter fetus, L. canicola-grippotyphosa-hardjo-

icterohaemorrhagiae-pomona bacterin

BHV-1, BVDV, PIV-3 live vaccine; L. canicola-grippotyphosa-hardjo-icterohaemorrhagiaepomona bacterin

BHV-1, BVDV, PIV-3, BRSV live vaccine; C. fetus, H. somnus, L. canicola-grippotyphosahardjo-icterohaemorrhagiae-pomona bacterin

BHV-1, BVDV, PIV-3, BRSV live vaccine; C. fetus, L. canicola-grippotyphosa-hardjo-

icterohaemorrhagiae-pomona bacterin

BHV-1, BVDV, PIV-3, BRSV live vaccine; H. somnus bacterin

BHV-1, BVDV, PIV-3, BRSV live vaccine; H. somnus, L. canicola-grippotyphosa-hardjo-

icterohaemorrhagiae-pomona bacterin

BHV-1, BVDV, PIV-3, BRSV live vaccine; L. canicola-grippotyphosa-hardjo-

icterohaemorrhagiae-pomona bacterin

BHV-1, BVDV, PIV-3, BRSV live vaccine; L. canicola-grippotyphosa-hardjo-

icterohaemorrhagiae-pomona-M. haemolytica bacterin

BHV-1, BVDV, PIV-3, BRSV live vaccine; L. hardjo bacterin

BHV-1, BVDV, PIV-3, BRSV live vaccine; M. haemolytica bacterin

BHV-1, BVDV, PIV-3, BRSV live vaccine; M. haemolytica toxoid

BHV-1, BVDV, PIV-3, BRSV live vaccine; M. haemolytica-P. multocida bacterin-toxoid

BHV-1, BVDV, PIV-3, BRSV live vaccine; L. pomona bacterin

$\mathrm{BRV}, \mathrm{BCoV}$ killed vaccine; C. perfringens type C, E. coli bacterin-toxoid

$\mathrm{BRV}, \mathrm{BCoV}$ killed vaccine; C. perfringens type $\mathrm{C}$ and $\mathrm{D}$, E. coli bacterin-toxoid

BRV, BCoV killed vaccine; E. coli bacterin

BVDV live vaccine; C. fetus, L. canicola-grippotyphosa-hardjo-icterohaemorrhagiae-

pomona bacterin

BVDV live vaccine; L. canicola-grippotyphosa-hardjo-icterohaemorrhagiae-pomona

bacterin

BVDV live vaccine; M. haemolytica toxoid

Trichomonas foetus vaccine, killed protozoa; C. fetus, L. canicola-grippotyphosa-hardjoicterohaemorrhagiae-pomona bacterin

C. botulinum type $\mathrm{C}$ bacterin-toxoid

C. chauvoei-septicum-haemolyticum-novyi-sordellii-perfringens types C and D bacterin-

toxoid

C. chauvoei-septicum-haemolyticum-novyi-sordellii-perfringens types $C$ and $D, H$. somnus bacterin-toxoid

C. chauvoei-septicum-haemolyticum-novyi-sordellii-perfringens types C and D, M.

haemolytica bacterin-toxoid

C. chauvoei-septicum-haemolyticum-novyi-sordellii-tetani-perfringens types C and D bacterin-toxoid

C. chauvoei-septicum-haemolyticum-novyi-tetani-perfringens types $C$ and D bacterin-

toxoid

C. chauvoei-septicum-novyi bacterin-toxoid

C. chauvoei-septicum-novyi-sordellii bacterin-toxoid

C. chauvoei-septicum-novyi-sordellii-perfringens types $C$ and D bacterin-toxoid

C. chauvoei-septicum-novyi-sordellii-perfringens types $C$ and D, H. somnus bacterintoxoid

C. chauvoei-septicum-novyi-sordellii-perfringens types $C$ and $D, M$. haemolytica bacterintoxoid

C. chauvoei-septicum-novyi-sordellii-perfringens types C and D, Moraxella bovis bacterintoxoid

C. perfringens type C, E. coli bacterin-toxoid

C. perfringens types $C$ and $D$ bacterin-toxoid

C. perfringens types $\mathrm{C}$ and $\mathrm{D}$-tetani bacterin-toxoid
Licensed producer

Effectiveness

SolidTech Animal Health

Biomune Company, Cambridge Technologies, Colorado

Serum Company, Elanco US, Hennessy Research

Associates, Huvepharma, Kennebec River Biosciences,

Newport Laboratories, Phibro Animal Health, Texas Vet Lab

Texas Vet Lab

Boehringer Ingelheim Vetmedica

Diamond Animal Health

Zoetis

Colorado Serum Company, Diamond Animal Health

Elanco US

Boehringer Ingelheim Vetmedica, Elanco US, Intervet,

Zoetis

Boehringer Ingelheim Vetmedica

Boehringer Ingelheim Vetmedica, Elanco US

Boehringer Ingelheim Vetmedica, Diamond Animal Health,

Elanco US, Intervet, Zoetis

Boehringer Ingelheim Vetmedica, Elanco US

Zoetis

Boehringer Ingelheim Vetmedica, Elanco US

Boehringer Ingelheim Vetmedica, Zoetis

Diamond Animal Health

Diamond Animal Health

Elanco US, Zoetis

Intervet

Zoetis

Zoetis

Zoetis

Zoetis

Boehringer Ingelheim Vetmedica, Elanco US

United Vaccines

Variable (165)

Boehringer Ingelheim Vetmedica, Intervet, Zoetis

Low-moderate

(166)

Intervet

Zoetis

Intervet

Intervet

Colorado Serum Company

Colorado Serum Company

Boehringer Ingelheim Vetmedica, Elanco US, Intervet,

Zoetis

Boehringer Ingelheim Vetmedica, Intervet, Zoetis

Zoetis

Boehringer Ingelheim Vetmedica, Intervet

Elanco US, Intervet, Zoetis

Effective (167)

Elanco US, Intervet, Zoetis

Intervet
Variable (160)

Low (162)

Variable (161)

Effective (163, 


Vaccine/type
C. tetani-perfringens type D, Corynebacterium pseudotuberculosis bacterin-toxoid
C. pseudotuberculosis bacterin-toxoid
E. coli bacterin-toxoid
H. somnus, M. haemolytica, P. multocida bacterin-toxoid
H. somnus, M. haemolytica-P. multocida, S. typhimurium bacterin-toxoid
M. haemolytica bacterial extract-toxoid
M. haemolytica bacterin-toxoid
M. haemolytica, P. multocida bacterin-toxoid
P. multocida bacterial extract-M. haemolytica toxoid
S. typhimurium bacterin-toxoid
S. aureus bacterin-toxoid
C. botulinum type B toxoid
C. perfringens type A toxoid
C. perfringens type C toxoid
C. perfringens type D toxoid
C. perfringens type D-tetanus toxoid
C. perfringens types C and D toxoid
C. perfringens types C and D-tetanus toxoid

Tetanus toxoid

\section{Licensed producer}

Colorado Serum Company

Boehringer Ingelheim Vetmedica, Colorado Serum Company

Merial

Texas Vet Lab

Texas Vet Lab

Elanco US

Boehringer Ingelheim Vetmedica, Elanco US, Zoetis

American Animal Health, Merial

Boehringer Ingelheim Vetmedica

Immvac

Hygieia Biological Laboratories

Neogen

Elanco US, Intervet

Colorado Serum Company

Colorado Serum Company

Colorado Serum Company

Boehringer Ingelheim Vetmedica, Colorado Serum Company

Boehringer Ingelheim Vetmedica, Colorado Serum Company

Boehringer Ingelheim Vetmedica, Colorado Serum Company, Intervet, Zoetis, Merck, Santa Cruz Animal Health
Effectiveness

Effective (168)

Variable (169)

Variable

Variable

Moderate

$(170,171)$

Effective (171)

Low (172)

Variable (169)

Variable (165)

Effective (167)

Effective (167)
Additional therapies have included maintenance of low abomasal $\mathrm{pH}$ to reduce numbers of pathogenic bacteria (such as salmonella), supplementation of short-chain fatty acids (acetate and propionate) to inhibit growth of pathogenic bacteria, homeopathic treatments (such as podophyllum or oregano), use of intestinal 'protectants' and 'absorbants' (such as kaolin, activated attapulgite, pectin, and activated charcoal), administration of agents that decrease intestinal motility, such as hyoscine N-butylbromide or atropine. However, clinical efficacy was very limited and needs further evaluation (174). Similarly, parenteral administration of mycobacterial cell wall extracts (189) had some efficacy in treatment of calf diarrhea, but wide-scale confirmatory evaluation studies have not been conducted.

Thus, there appears to be no broadly applicable therapeutic treatments (with the exception IgY, ORT and antibiotics) that could drastically improve health of dairy cattle. The most practical approach should likely rely on a combination therapy utilizing passive immune protection, vaccination and supplemental treatments using probiotics/probiotic products.

\section{CONCLUDING REMARKS}

The insufficient basic knowledge of bovine immune function and the lack of a developed toolbox for immunological studies hinder our ability to generate and maintain optimal cattle health. This is especially challenging for newborn dairy calves (due to immune immaturity) and dairy cows during the transition period (due to metabolic and immune dysfunction). Further evaluation and optimization of the existing vaccines in large-scale field trials are critical. In-depth studies of the influence of various macro- and micronutrients and commensal and probiotic bacteria on bovine immune function will likely yield novel and urgently needed interventions to combat infectious diseases and inflammatory disorders in cattle. The existing evidence suggests that provision of cow colostrum and milk in sufficient amounts in the first week of life and optimization of cattle feeding according to the production stage and group promote immune development and help to maintain immune function and should be widely adopted. Additionally, emerging evidence suggest that a second colostrum feeding soon after the first one may provide appreciable health benefits. Routine immunizations of calves, heifers and pregnant cows against vaccine-preventable diseases and elimination of the pathogens that subvert or compromise the immune system and are essential strategies that can help to maintain a healthy herd. Further, conducting additional research to determine optimal timing for vaccination and application of novel vaccines and adjuvants (micronutrients, probiotics, etc) will allow improved vaccines and vaccination protocols (such as vaccination of recently transported stressed cattle) to achieve better protection by new or existing vaccines. Finally, a combination of available ancillary strategies discussed above, including pro- and prebiotic feeding, IgY Ab supplementation, controlling abomasal $\mathrm{pH}$ and preserving epithelial integrity as well as minimizing the use of antimicrobials are expected to have a positive impact on dairy production.

\section{AUTHOR CONTRIBUTIONS}

AV generated the initial draft. AV and LS have revised the final content critically. All authors contributed to the article and approved the submitted version. 


\section{REFERENCES}

1. Meade KG. Advances in Bovine Immunology - New Tools and New Insights to Tackle Old Foes. Front Immunol (2015) 6:71. doi: 10.3389/fimmu.2015.00071

2. Schiller I, Oesch B, Vordermeier HM, Palmer MV, Harris BN, Orloski KA, et al. Bovine Tuberculosis: A Review of Current and Emerging Diagnostic Techniques in View of Their Relevance for Disease Control and Eradication. Transbound Emerging Dis (2010) 57(4):205-20. doi: 10.1111/j.1865-1682.2010.01148.x

3. Site Bd-Td. Available at: https://www.thedairysite.com/focus/thermo-fisherscientific/2334/bovine-diagnostics.

4. McGill JL, Sacco RE. The Immunology of Bovine Respiratory Disease: Recent Advancements. Vet Clin North Am Food Anim Pract (2020) 36 (2):333-48. doi: 10.1016/j.cvfa.2020.03.002

5. Saif LJ. Bovine Respiratory Coronavirus. Vet Clin North Am Food Anim Pract (2010) 26(2):349-64. doi: 10.1016/j.cvfa.2010.04.005

6. Fulton RW, Herd HR, Sorensen NJ, Confer AW, Ritchey JW, Ridpath JF, et al. Enteric Disease in Postweaned Beef Calves Associated With Bovine Coronavirus Clade 2. J Vet Diagn Invest: Off Publ Am Assoc Vet Lab Diagn Inc (2015) 27(1):97-101. doi: 10.1177/1040638714559026

7. Smith G. Antimicrobial Decision Making for Enteric Diseases of Cattle. Vet Clin North Am Food Anim Pract (2015) 31(1):47-60. doi: 10.1016/ j.cvfa.2014.11.004

8. Holschbach CL, Peek SF. Salmonella in Dairy Cattle. Vet Clin North Am Food Anim Pract (2018) 34(1):133-54. doi: 10.1016/j.cvfa.2017.10.005

9. Toka FN, Golde WT. Cell Mediated Innate Responses of Cattle and Swine Are Diverse During Foot-and-Mouth Disease Virus (FMDV) Infection: A Unique Landscape of Innate Immunity. Immunol Lett (2013) 152(2):13543. doi: 10.1016/j.imlet.2013.05.007

10. Tomley FM, Shirley MW. Livestock Infectious Diseases and Zoonoses. In: Biological Sciences, vol. 364. London, United Kingdom: Philosophical transactions of the Royal Society of London Series B (2009). p. 2637-42.

11. Konnai S, Murata S, Ohashi K. Immune Exhaustion During Chronic Infections in Cattle. J Vet Med Sci (2017) 79(1):1-5. doi: 10.1292/jvms.16-0354

12. Ohira K, Nakahara A, Konnai S, Okagawa T, Nishimori A, Maekawa N, et al. Bovine Leukemia Virus Reduces Anti-Viral Cytokine Activities and NK Cytotoxicity by Inducing TGF-Beta Secretion From Regulatory T Cells. Immunity Inflamm Dis (2016) 4(1):52-63. doi: 10.1002/iid3.93

13. McDaniel CJ, Cardwell DM, Moeller RB Jr, Gray GC. Humans and Cattle: A Review of Bovine Zoonoses. Vector Borne Zoonotic Dis (2014) 14(1):1-19. doi: 10.1089/vbz.2012.1164

14. Ackermann MR, Derscheid R, Roth JA. Innate Immunology of Bovine Respiratory Disease. Vet Clin North Am Food Anim Pract (2010) 26(2):21528. doi: 10.1016/j.cvfa.2010.03.001

15. Ferluga J, Yasmin H, Al-Ahdal MN, Bhakta S, Kishore U. Natural and Trained Innate Immunity Against Mycobacterium Tuberculosis. Immunobiology (2020) 225(3):151951. doi: 10.1016/j.imbio.2020.151951

16. Levings RL, Roth JA. Immunity to Bovine Herpesvirus 1: I. Viral Lifecycle Innate Immunity. Anim Health Res Rev (2013) 14(1):88-102. doi: 10.1017/ S1466252313000042

17. Chase CC, Hurley DJ, Reber AJ. Neonatal Immune Development in the Calf and Its Impact on Vaccine Response. Vet Clin North Am Food Anim Pract (2008) 24(1):87-104. doi: 10.1016/j.cvfa.2007.11.001

18. Novak K. Functional Polymorphisms in Toll-Like Receptor Genes for Innate Immunity in Farm Animals. Vet Immunol Immunopathol (2014) 157(12):1-11. doi: 10.1016/j.vetimm.2013.10.016

19. Bannerman DD. Pathogen-Dependent Induction of Cytokines and Other Soluble Inflammatory Mediators During Intramammary Infection of Dairy Cows. J Anim Sci (2009) 87(13 Suppl):10-25. doi: 10.2527/jas.2008-1187

20. Kuther K, Audige L, Kube P, Welle M. Bovine Mast Cells: Distribution, Density, Heterogeneity, and Influence of Fixation Techniques. Cell Tissue Res (1998) 293(1):111-9. doi: 10.1007/s004410051103

21. Belluzzi S, Galeotti M, Eutizi CM, Castagnetti C. The Correlation Between Mast Cells and Some Inflammatory Mediators in the Bovine Endometrium. Vet Res Commun (2004) 28(Suppl 1):165-8. doi: 10.1023/B:VERC. $0000045397.58562 .6 \mathrm{~b}$

22. Chen W, Alley MR, Manktelow BW, Slack P. Mast Cells in the Bovine Lower Respiratory Tract: Morphology, Density and Distribution. Br Vet J (1990) 146(5):425-36. doi: 10.1016/0007-1935(90)90031-W
23. Raphael W, Sordillo LM. Dietary Polyunsaturated Fatty Acids and Inflammation: The Role of Phospholipid Biosynthesis. Int J Mol Sci (2013) 14(10):21167-88. doi: 10.3390/ijms141021167

24. Sordillo LM, Raphael W. Significance of Metabolic Stress, Lipid Mobilization, and Inflammation on Transition Cow Disorders. Vet Clin North Am Food Anim Pract (2013) 29(2):267-78. doi: 10.1016/ j.cvfa.2013.03.002

25. Ploegaert TC, Tijhaar E, Lam TJ, Taverne-Thiele A, van der Poel JJ, van Arendonk JA, et al. Natural Antibodies in Bovine Milk and Blood Plasma: Variability Among Cows, Repeatability Within Cows, and Relation Between Milk and Plasma Titers. Vet Immunol Immunopathol (2011) 144(1-2):8894. doi: 10.1016/j.vetimm.2011.07.008

26. Korhonen H, Marnila P, Gill HS. Milk Immunoglobulins and Complement Factors. Br J Nutr (2000) 84(Suppl 1):S75-80. doi: 10.1017/S00071145 00002282

27. Rainard P. The Complement in Milk and Defense of the Bovine Mammary Gland Against Infections. Vet Res (2003) 34(5):647-70. doi: 10.1051/ vetres:2003025

28. Stanfield RL, Haakenson J, Deiss TC, Criscitiello MF, Wilson IA, Smider VV. The Unusual Genetics and Biochemistry of Bovine Immunoglobulins. Adv Immunol (2018) 137:135-64. doi: 10.1016/bs.ai.2017.12.004

29. Zhuang Y, Futse JE, Brown WC, Brayton KA, Palmer GH. Maintenance of Antibody to Pathogen Epitopes Generated by Segmental Gene Conversion Is Highly Dynamic During Long-Term Persistent Infection. Infect Immunity (2007) 75(11):5185-90. doi: 10.1128/IAI.00913-07

30. Wang F, Ekiert DC, Ahmad I, Yu W, Zhang Y, Bazirgan O, et al. Reshaping Antibody Diversity. Cell (2013) 153(6):1379-93. doi: 10.1016/j.cell.2013.04.049

31. Wilkie BN. Review of Bovine Immunology for the Veterinary Practitioner. Can Vet J = La Rev Vet Canadienne (1974) 15(9):243-8.

32. Maunsell FP, Chase C. Mycoplasma Bovis: Interactions With the Immune System and Failure to Generate an Effective Immune Response. Vet Clin North Am Food Anim Pract (2019) 35(3):471-83. doi: 10.1016/j.cvfa 2019.08.003

33. Connelley T, MacHugh ND, Burrells A, Morrison WI. Dissection of the Clonal Composition of Bovine Alphabeta T Cell Responses Using T Cell Receptor Vbeta Subfamily-Specific PCR and Heteroduplex Analysis. J Immunol Methods (2008) 335(1-2):28-40. doi: 10.1016/j.jim.2008.02.015

34. Neefjes J, Jongsma ML, Paul P, Bakke O. Towards a Systems Understanding of MHC Class I and MHC Class II Antigen Presentation. Nat Rev Immunol (2011) 11(12):823-36. doi: 10.1038/nri3084

35. Wyckoff JH 3rd. Bovine T Lymphocyte Responses to Brucella Abortus. Vet Microbiol (2002) 90(1-4):395-415. doi: 10.1016/S0378-1135(02)00224-9

36. Morrison LA, Lukacher AE, Braciale VL, Fan DP, Braciale TJ. Differences in Antigen Presentation to MHC Class I- And Class II-Restricted Influenza Virus-Specific Cytolytic T Lymphocyte Clones. J Exp Med (1986) Apr 1163 (4):903-21. doi: 10.1084/jem.163.4.903

37. Nene V, Svitek N, Toye P, Golde WT, Barlow J, Harndahl M, et al. Designing Bovine $\mathrm{T}$ Cell Vaccines via Reverse Immunology. Ticks Tick-Borne Dis (2012) 3(3):188-92. doi: 10.1016/j.ttbdis.2011.12.001

38. Endsley JJ, Roth JA, Ridpath J, Neill J. Maternal Antibody Blocks Humoral But Not T Cell Responses to BVDV. Biol: J Int Assoc Biol Standardization (2003) 31(2):123-5. doi: 10.1016/S1045-1056(03)00027-7

39. Brown WC, Rice-Ficht AC, Estes DM. Bovine Type 1 and Type 2 Responses. Vet Immunol Immunopathol (1998) 63(1-2):45-55. doi: 10.1016/s0165-2427 (98)00081-6

40. Welsh MD, Cunningham RT, Corbett DM, Girvin RM, McNair J, Skuce RA, et al. Influence of Pathological Progression on the Balance Between Cellular and Humoral Immune Responses in Bovine Tuberculosis. Immunology (2005) 114(1):101-11. doi: 10.1111/j.1365-2567.2004.02003.x

41. Abrahamsen MS. Bovine T Cell Responses to Cryptosporidium Parvum Infection. Int J Parasitol (1998) 28(7):1083-8. doi: 10.1016/S0020-7519(98) 00077-0

42. Chase C, Kaushik RS. Mucosal Immune System of Cattle: All Immune Responses Begin Here. Vet Clin North Am Food Anim Pract (2019) 35 (3):431-51. doi: 10.1016/j.cvfa.2019.08.006

43. Gomez DE, Galvao KN, Rodriguez-Lecompte JC, Costa MC. The Cattle Microbiota and the Immune System: An Evolving Field. Vet Clin North Am Food Anim Pract (2019) 35(3):485-505. doi: 10.1016/j.cvfa.2019.08.002 
44. Malmuthuge N, Li M, Goonewardene LA, Oba M, Guan LL. Effect of Calf Starter Feeding on Gut Microbial Diversity and Expression of Genes Involved in Host Immune Responses and Tight Junctions in Dairy Calves During Weaning Transition. J Dairy Sci (2013) 96(5):3189-200. doi: $10.3168 /$ jds.2012-6200

45. Niemiałtowski M, Schollenberger A, Kluciński W. Mucosal Immunity and the Bovine Entero-Mammary Link: Evolutionary Established Dialogue Between Antigen and Arms of Immune System. In: Holzapfel WH, Naughton PJ, Pierzynowski SG, Zabielski R, Salek E, editors. Microbial Ecology of Growing Animals, vol. 2. London, United Kingdom: Elsevier (2005). p. 293-313.

46. Villena J, Aso H, Kitazawa H. Regulation of Toll-Like Receptors-Mediated Inflammation by Immunobiotics in Bovine Intestinal Epitheliocytes: Role of Signaling Pathways and Negative Regulators. Front Immunol (2014) 5:421. doi: 10.3389/fimmu.2014.00421

47. McClenahan DJ, Sotos JP, Czuprynski CJ. Cytokine Response of Bovine Mammary Gland Epithelial Cells to Escherichia Coli, Coliform Culture Filtrate, or Lipopolysaccharide. Am J Vet Res (2005) 66(9):1590-7. doi: 10.2460/ajvr.2005.66.1590

48. Kim D, Yoo SA, Kim WU. Gut Microbiota in Autoimmunity: Potential for Clinical Applications. Arch Pharmacal Res (2016) 39(11):1565-76. doi: 10.1007/s12272-016-0796-7

49. Cunha P, Vern YL, Gitton C, Germon P, Foucras G, Rainard P. Expansion, Isolation and First Characterization of Bovine Th17 Lymphocytes. Sci Rep (2019) 9(1):16115. doi: 10.1038/s41598-019-52562-2

50. Trevisi E, Riva F, Filipe JFS, Massara M, Minuti A, Bani P, et al. Innate Immune Responses to Metabolic Stress Can be Detected in Rumen Fluids. Res Vet Sci (2018) 117:65-73. doi: 10.1016/j.rvsc.2017.11.008

51. Aditya S, Humer E, Pourazad P, Khiaosa-Ard R, Huber J, Zebeli Q. Intramammary Infusion of Escherichia Coli Lipopolysaccharide Negatively Affects Feed Intake, Chewing, and Clinical Variables, But Some Effects Are Stronger in Cows Experiencing Subacute Rumen Acidosis. J Dairy Sci (2017) 100(2):1363-77. doi: 10.3168/jds.2016-11796

52. Brandtzaeg P. Potential of Nasopharynx-Associated Lymphoid Tissue for Vaccine Responses in the Airways. Am J Respir Crit Care Med (2011) 183 (12):1595-604. doi: 10.1164/rccm.201011-1783OC

53. Brandtzaeg P, Kiyono H, Pabst R, Russell MW. Terminology: Nomenclature of Mucosa-Associated Lymphoid Tissue. Mucosal Immunol (2008) 1(1):317. doi: $10.1038 / \mathrm{mi} .2007 .9$

54. Wira CR, Fahey JV, Rodriguez-Garcia M, Shen Z, Patel MV. Regulation of Mucosal Immunity in the Female Reproductive Tract: The Role of Sex Hormones in Immune Protection Against Sexually Transmitted Pathogens. Am J Reprod Immunol (2014) 72(2):236-58. doi: 10.1111/aji.12252

55. Inman CF, Haverson K, Konstantinov SR, Jones PH, Harris C, Smidt H, et al. Rearing Environment Affects Development of the Immune System in Neonates. Clin Exp Immunol (2010) 160(3):431-9. doi: 10.1111/j.13652249.2010.04090.x

56. Young W, Hine BC, Wallace OA, Callaghan M, Bibiloni R. Transfer of Intestinal Bacterial Components to Mammary Secretions in the Cow. PeerJ (2015) 3:e888. doi: 10.7717/peerj.888

57. Widders PR, Paisley LG, Gogolewski RP, Evermann JF, Smith JW, Corbeil LB. Experimental Abortion and the Systemic Immune Response to "Haemophilus Somnus" in Cattle. Infect Immun (1986) 54(2):555-60. doi: 10.1128/iai.54.2.555-560.1986

58. Leitner G, Yadlin B, Glickman A, Chaffer M, Saran A. Systemic and Local Immune Response of Cows to Intramammary Infection With Staphylococcus Aureus. Res Vet Sci (2000) 69(2):181-4. doi: 10.1053/rvsc.2000.0409

59. Eschbaumer M, Stenfeldt C, Rekant SI, Pacheco JM, Hartwig EJ, Smoliga GR, et al. Systemic Immune Response and Virus Persistence After Foot-andMouth Disease Virus Infection of Naive Cattle and Cattle Vaccinated With a Homologous Adenovirus-Vectored Vaccine. BMC Vet Res (2016) 12:205. doi: 10.1186/s12917-016-0838-x

60. Kimman TG, Westenbrink F, Schreuder BE, Straver PJ. Local and Systemic Antibody Response to Bovine Respiratory Syncytial Virus Infection and Reinfection in Calves With and Without Maternal Antibodies. J Clin Microbiol (1987) 25(6):1097-106. doi: 10.1128/jcm.25.6.1097-1106.1987

61. Ko AI, Goarant C, Picardeau M. Leptospira: The Dawn of the Molecular Genetics Era for an Emerging Zoonotic Pathogen. Nat Rev Microbiol (2009) 7(10):736-47. doi: 10.1038/nrmicro2208
62. Santecchia I, Vernel-Pauillac F, Rasid O, Quintin J, Gomes-Solecki M, Boneca IG, et al. Innate Immune Memory Through TLR2 and NOD2 Contributes to the Control of Leptospira Interrogans Infection. PloS Pathogens (2019) 15(5):e1007811. doi: 10.1371/journal.ppat.1007811

63. Peterhans E, Jungi TW, Schweizer M. BVDV and Innate Immunity. Biol: $J$ Int Assoc Biol Standardization (2003) 31(2):107-12. doi: 10.1016/S10451056(03)00024-1

64. Schaut RG, Ridpath JF, Sacco RE. Bovine Viral Diarrhea Virus Type 2 Impairs Macrophage Responsiveness to Toll-Like Receptor Ligation With the Exception of Toll-Like Receptor 7. PloS One (2016) 11(7):e0159491. doi: 10.1371/journal.pone.0159491

65. Schaut RG, McGill JL, Neill JD, Ridpath JF, Sacco RE. Bovine Viral Diarrhea Virus Type 2 In Vivo Infection Modulates TLR4 Responsiveness in Differentiated Myeloid Cells Which Is Associated With Decreased MyD88 Expression. Virus Res (2015) 208:44-55. doi: 10.1016/j.virusres.2015.05.017

66. Suzuki S, Konnai S, Okagawa T, Ikebuchi R, Shirai T, Sunden Y, et al. Expression Analysis of Foxp3 in T Cells From Bovine Leukemia Virus Infected Cattle. Microbiol Immunol (2013) 57(8):600-4. doi: 10.1111/13480421.12073

67. Ikebuchi R, Konnai S, Shirai T, Sunden Y, Murata S, Onuma M, et al. Increase of Cells Expressing PD-L1 in Bovine Leukemia Virus Infection and Enhancement of Anti-Viral Immune Responses In Vitro via PD-L1 Blockade. Vet Res (2011) 42:103. doi: 10.1186/1297-9716-42-103

68. Roussey JA, Steibel JP, Coussens PM. Regulatory T Cell Activity and Signs of T Cell Unresponsiveness in Bovine Paratuberculosis. Front Vet Sci (2014) 1:20. doi: $10.3389 /$ fvets.2014.00020

69. Leite FL, Eslabao LB, Pesch B, Bannantine JP, Reinhardt TA, Stabel JR. ZAP70, CTLA-4 and Proximal T Cell Receptor Signaling in Cows Infected With Mycobacterium Avium Subsp. Paratuberculosis. Vet Immunol Immunopathol (2015) 167(1-2):15-21. doi: 10.1016/j.vetimm.2015.06.017

70. Okagawa T, Konnai S, Nishimori A, Ikebuchi R, Mizorogi S, Nagata R, et al. Bovine Immunoinhibitory Receptors Contribute to Suppression of Mycobacterium Avium Subsp. Paratuberculosis-Specific T-Cell Responses. Infect Immun (2016) 84(1):77-89. doi: 10.1128/IAI.01014-15

71. Okagawa T, Konnai S, Deringer JR, Ueti MW, Scoles GA, Murata S, et al. Cooperation of PD-1 and LAG-3 Contributes to T-Cell Exhaustion in Anaplasma Marginale-Infected Cattle. Infect Immun (2016) Oct84 (10):2779-90. doi: 10.1128/IAI.00278-16

72. Palomares RA, Hurley DJ, Woolums AR, Parrish JE, Brock KV. Analysis of mRNA Expression for Genes Associated With Regulatory T Lymphocytes (CD25, FoxP3, CTLA4, and IDO) After Experimental Infection With Bovine Viral Diarrhea Virus of Low or High Virulence in Beef Calves. Comp Immunol Microbiol Infect Dis (2014) 37(5-6):331-8. doi: 10.1016/ j.cimid.2014.10.001

73. Arzt J, Baxt B, Grubman MJ, Jackson T, Juleff N, Rhyan J, et al. The Pathogenesis of Foot-and-Mouth Disease II: Viral Pathways in Swine, Small Ruminants, and Wildlife; Myotropism, Chronic Syndromes, and Molecular Virus-Host Interactions. Transbound Emerging Dis (2011) 58(4):305-26. doi: 10.1111/j.1865-1682.2011.01236.x

74. Oikonomou G, Teixeira AG, Foditsch C, Bicalho ML, Machado VS, Bicalho RC. Fecal Microbial Diversity in Pre-Weaned Dairy Calves as Described by Pyrosequencing of Metagenomic 16S rDNA. Associations of Faecalibacterium Species With Health and Growth. PloS One (2013) 8(4): e63157. doi: 10.1371/journal.pone.0063157

75. Willing BP, Gill N, Finlay BB. The Role of the Immune System in Regulating the Microbiota. Gut Microbes (2010) 1(4):213-23. doi: 10.4161/gmic.1.4.12520

76. Mackie RI, Sghir A, Gaskins HR. Developmental Microbial Ecology of the Neonatal Gastrointestinal Tract. Am J Clin Nutr (1999) 69(5):1035S-45S. doi: $10.1093 /$ ajcn/69.5.1035s

77. Chase CCL. Enteric Immunity: Happy Gut, Healthy Animal. Vet Clin North Am Food Anim Pract (2018) 34(1):1-18. doi: 10.1016/j.cvfa.2017.10.006

78. Matthews C, Crispie F, Lewis E, Reid M, O'Toole PW, Cotter PD. The Rumen Microbiome: A Crucial Consideration When Optimising Milk and Meat Production and Nitrogen Utilisation Efficiency. Gut Microbes (2019) 10(2):115-32. doi: 10.1080/19490976.2018.1505176

79. Lettat A, Benchaar C. Diet-Induced Alterations in Total and Metabolically Active Microbes Within the Rumen of Dairy Cows. PloS One (2013) 8(4): e60978. doi: 10.1371/journal.pone.0060978 
80. Hungate RE. CHAPTER VII - Conversions of Nitrogenous Materials. In: The Rumen and Its Microbes. New York, New York, United States of America and London, United Kingdom: Academic Press (1966). p. 281-330.

81. Brulc JM, Antonopoulos DA, Miller ME, Wilson MK, Yannarell AC, Dinsdale EA, et al. Gene-Centric Metagenomics of the Fiber-Adherent Bovine Rumen Microbiome Reveals Forage Specific Glycoside Hydrolases. Proc Natl Acad Sci USA (2009) 106(6):1948-53. doi: 10.1073/pnas.0806191105

82. Xue MY, Sun HZ, Wu XH, Liu JX, Guan LL. Multi-Omics Reveals That the Rumen Microbiome and Its Metabolome Together With the Host Metabolome Contribute to Individualized Dairy Cow Performance. Microbiome (2020) 8(1):64. doi: 10.1186/s40168-020-00819-8

83. Barrington GM, Parish SM. Bovine Neonatal Immunology. Vet Clin North Am Food Anim Pract (2001) 17(3):463-76. doi: 10.1016/S0749-0720(15) 30001-3

84. Sultana R, McBain AJ, O’Neill CA. Strain-Dependent Augmentation of Tight-Junction Barrier Function in Human Primary Epidermal Keratinocytes by Lactobacillus and Bifidobacterium Lysates. Appl Environ Microbiol (2013) 79(16):4887-94. doi: 10.1128/AEM.00982-13

85. Enss ML, Grosse-Siestrup H, Schmidt-Wittig U, Gartner K. Changes in Colonic Mucins of Germfree Rats in Response to the Introduction of a "Normal" Rat Microbial Flora. Rat Colonic Mucin. J Exp Anim Sci (1992) 35(3):110-9.

86. Cunningham-Rundles C. Physiology of IgA and IgA Deficiency. J Clin Immunol (2001) 21(5):303-9. doi: 10.1023/A:1012241117984

87. Gomez DE, Arroyo LG, Costa MC, Viel L, Weese JS. Characterization of the Fecal Bacterial Microbiota of Healthy and Diarrheic Dairy Calves. J Vet Internal Med (2017) 31(3):928-39. doi: 10.1111/jvim.14695

88. Malmuthuge N, Li M, Fries P, Griebel PJ, Guan LL. Regional and Age Dependent Changes in Gene Expression of Toll-Like Receptors and Key Antimicrobial Defence Molecules Throughout the Gastrointestinal Tract of Dairy Calves. Vet Immunol Immunopathol (2012) 146(1):18-26. doi: 10.1016/j.vetimm.2012.01.010

89. Weng M, Walker WA. The Role of Gut Microbiota in Programming the Immune Phenotype. J Dev Origins Health Dis (2013) J4(3):203-14. doi: 10.1017/S2040174412000712

90. Derakhshani H, De Buck J, Mortier R, Barkema HW, Krause DO, Khafipour E. The Features of Fecal and Ileal Mucosa-Associated Microbiota in Dairy Calves During Early Infection With Mycobacterium Avium Subspecies Paratuberculosis. Front Microbiol (2016) 7:426. doi: 10.3389/fmicb.2016.00426

91. Gulbe G, Pilmane M, Saulite V, Donina S, Jermolajevs J, Peskova L, et al. Cells and Cytokines in Milk of Subclinically Infected Bovine Mammary Glands After the Use of Immunomodulatory Composition GLP 810. Mediators Inflamm (2020) 2020:8238029. doi: 10.1155/2020/8238029

92. Sordillo LM. Nutritional Strategies to Optimize Dairy Cattle Immunity. J Dairy Sci (2016) 99(6):4967-82. doi: 10.3168/jds.2015-10354

93. Heuer C, Schukken YH, Dobbelaar P. Postpartum Body Condition Score and Results From the First Test Day Milk as Predictors of Disease, Fertility, Yield, and Culling in Commercial Dairy Herds. J Dairy Sci (1999) 82(2):295304. doi: 10.3168/jds.S0022-0302(99)75236-7

94. Haubold S, Kroger-Koch C, Starke A, Tuchscherer A, Troscher A, Kienberger H, et al. Effects of Abomasal Infusion of Essential Fatty Acids and Conjugated Linoleic Acid on Performance and Fatty Acid, Antioxidative, and Inflammatory Status in Dairy Cows. J Dairy Sci (2020) 103(1):972-91. doi: 10.3168/jds.2019-17135

95. Zhao XJ, Li ZP, Wang JH, Xing XM, Wang ZY, Wang L, et al. Effects of Chelated $\mathrm{Zn} / \mathrm{Cu} / \mathrm{Mn}$ on Redox Status, Immune Responses and Hoof Health in Lactating Holstein Cows. J Vet Sci (2015) 16(4):439-46. doi: 10.4142/ jvs.2015.16.4.439

96. Caroprese M, Marzano A, Entrican G, Wattegedera S, Albenzio M, Sevi A. Immune Response of Cows Fed Polyunsaturated Fatty Acids Under High Ambient Temperatures. J Dairy Sci (2009) 92(6):2796-803. doi: 10.3168/ jds.2008-1809

97. Calder PC. Editorial: Fat Chance to Enhance B Cell Function. J Leukocyte Biol (2013) 93(4):457-9. doi: 10.1189/jlb.1212646

98. Galyean ML, Perino LJ, Duff GC. Interaction of Cattle Health/Immunity and Nutrition. J Anim Sci (1999) 77(5):1120-34. doi: 10.2527/1999.7751120x

99. Kvidera SK, Horst EA, Abuajamieh M, Mayorga EJ, Fernandez MV, Baumgard LH. Glucose Requirements of an Activated Immune System in
Lactating Holstein Cows. J Dairy Sci (2017) 100(3):2360-74. doi: 10.3168/ jds.2016-12001

100. Caroprese M, Albenzio M, Marino R, Santillo A, Sevi A. Dietary Glutamine Enhances Immune Responses of Dairy Cows Under High Ambient Temperature. J Dairy Sci (2013) 96(5):3002-11. doi: 10.3168/jds.2012-6306

101. Bai M, Liu H, Xu K, Oso AO, Wu X, Liu G, et al. A Review of the Immunomodulatory Role of Dietary Tryptophan in Livestock and Poultry. Amino Acids (2017) 49(1):67-74. doi: 10.1007/s00726-016-2351-8

102. Hemingway RG. The Influences of Dietary Selenium and Vitamin E Intakes on Milk Somatic Cell Counts and Mastitis in Cows. Vet Res Commun (1999) 23(8):481-99. doi: 10.1023/a:1006362422945

103. Reddy PG, Frey RA. Nutritional Modulation of Immunity in Domestic Food Animals. Adv Vet Sci Comp Med (1990) 35:255-81. doi: 10.1016/B978-0-12039235-3.50016-2

104. Spears JW. Micronutrients and Immune Function in Cattle. Proc Nutr Soc (2000) 59(4):587-94. doi: 10.1017/S0029665100000835

105. Gygax M, Hirni H, Zwahlen R, Lazary S, Blum JW. Immune Functions of Veal Calves Fed Low Amounts of Iron. Zentralblatt Fur Veterinarmed Reihe A (1993) 40(5):345-58. doi: 10.1111/j.1439-0442.1993.tb00638.x

106. Van Emon M, Sanford C, McCoski S. Impacts of Bovine Trace Mineral Supplementation on Maternal and Offspring Production and Health. Animals: An Open Access J MDPI (2020) 10(12):2404. doi: 10.3390/ ani10122404

107. Nelson CD, Reinhardt TA, Lippolis JD, Sacco RE, Nonnecke BJ. Vitamin D Signaling in the Bovine Immune System: A Model for Understanding Human Vitamin D Requirements. Nutrients (2012) 4(3):181-96. doi: 10.3390/nu4030181

108. Cummins KA, Brunner CJ. Dietary Ascorbic Acid and Immune Response in Dairy Calves. J Dairy Sci (1989) 72(1):129-34. doi: 10.3168/jds.S0022-0302 (89)79088-3

109. Andrieu S. Is There a Role for Organic Trace Element Supplements in Transition Cow Health? Vet J (2008) 176(1):77-83. doi: 10.1016/ j.tvjl.2007.12.022

110. Spears JW, Weiss WP. Role of Antioxidants and Trace Elements in Health and Immunity of Transition Dairy Cows. Vet J (2008) 176(1):70-6. doi: 10.1016/j.tvjl.2007.12.015

111. Sordillo LM, Aitken SL. Impact of Oxidative Stress on the Health and Immune Function of Dairy Cattle. Vet Immunol Immunopathol (2009) 128 (1-3):104-9. doi: 10.1016/j.vetimm.2008.10.305

112. Lee JS, Priatno W, Ghassemi Nejad J, Peng DQ, Park JS, Moon JO, et al. Effect of Dietary Rumen-Protected L-Tryptophan Supplementation on Growth Performance, Blood Hematological and Biochemical Profiles, and Gene Expression in Korean Native Steers Under Cold Environment. Animals: An Open Access J MDPI (2019) 9(12):1036. doi: 10.3390/ani9121036

113. Ingvartsen KL, Moyes K. Nutrition, Immune Function and Health of Dairy Cattle. Animal: An Int J Anim Biosci (2013) 7 Suppl 1:112-22. doi: 10.1017/ S175173111200170X

114. Ott TL. Symposium Review: Immunological Detection of the Bovine Conceptus During Early Pregnancy. J Dairy Sci (2019) 102(4):3766-77. doi: 10.3168/jds.2018-15668

115. Talukder AK, Yousef MS, Rashid MB, Awai K, Acosta TJ, Shimizu T, et al. Bovine Embryo Induces an Anti-Inflammatory Response in Uterine Epithelial Cells and Immune Cells In Vitro: Possible Involvement of Interferon Tau as an Intermediator. J Reprod Dev (2017) 63(4):425-34. doi: 10.1262/jrd.2017-056

116. Oliveira LJ, Barreto RS, Perecin F, Mansouri-Attia N, Pereira FT, Meirelles FV. Modulation of Maternal Immune System During Pregnancy in the Cow. Reprod Domest Anim = Zuchthyg (2012) 47(Suppl 4):384-93. doi: 10.1111/ j.1439-0531.2012.02102.x

117. Mansouri-Attia N, Oliveira LJ, Forde N, Fahey AG, Browne JA, Roche JF, et al. Pivotal Role for Monocytes/Macrophages and Dendritic Cells in Maternal Immune Response to the Developing Embryo in Cattle. Biol Reproduct (2012) 87(5):123. doi: 10.1095/biolreprod.112.101121

118. Oliveira LJ, McClellan S, Hansen PJ. Differentiation of the Endometrial Macrophage During Pregnancy in the Cow. PloS One (2010) 5(10):e13213. doi: 10.1371/journal.pone.0013213

119. O'Gorman GM, Al Naib A, Ellis SA, Mamo S, O’Doherty AM, Lonergan P, et al. Regulation of a Bovine Nonclassical Major Histocompatibility Complex 
Class I Gene Promoter. Biol Reproduct (2010) 83(2):296-306. doi: 10.1095/ biolreprod.109.082560

120. Al Naib A, Mamo S, O'Gorman GM, Lonergan P, Swales A, Fair T. Regulation of Non-Classical Major Histocompatability Complex Class I mRNA Expression in Bovine Embryos. J Reprod Immunol (2011) 91(12):31-40. doi: 10.1016/j.jri.2011.05.005

121. Paibomesai MA, Sharif S, Karrow N, Mallard BA. Type I and Type II Cytokine Production of CD4+ T-Cells in Immune Response Biased Dairy Cattle Around Calving. Vet Immunol Immunopathol (2018) 199:70-6. doi: 10.1016/j.vetimm.2018.03.001

122. Maeda Y, Ohtsuka H, Tomioka M, Oikawa M. Effect of Progesterone on Th1/Th2/Th17 and Regulatory T Cell-Related Genes in Peripheral Blood Mononuclear Cells During Pregnancy in Cows. Vet Res Commun (2013) 37 (1):43-9. doi: 10.1007/s11259-012-9545-7

123. Trevisi E, Minuti A. Assessment of the Innate Immune Response in the Periparturient Cow. Res Vet Sci (2018) 116:47-54. doi: 10.1016/j.rvsc.2017.12.001

124. Detilleux JC, Kehrli ME Jr, Stabel JR, Freeman AE, Kelley DH. Study of Immunological Dysfunction in Periparturient Holstein Cattle Selected for High and Average Milk Production. Vet Immunol Immunopathol (1995) 44 (3-4):251-67. doi: 10.1016/0165-2427(94)05302-9

125. Meglia GE, Johannisson A, Petersson L, Waller KP. Changes in Some Blood Micronutrients, Leukocytes and Neutrophil Expression of Adhesion Molecules in Periparturient Dairy Cows. Acta Vet Scand (2001) 42(1):13950. doi: 10.1186/1751-0147-42-139

126. Heyland DK, Dhaliwal R, Day AG, Muscedere J, Drover J, Suchner U, et al. REducing Deaths Due to OXidative Stress (The REDOXS Study): Rationale and Study Design for a Randomized Trial of Glutamine and Antioxidant Supplementation in Critically-Ill Patients. Proc Nutr Soc (2006) 65(3):25063. doi: $10.1079 /$ PNS2006505

127. Benedictus L, Thomas AJ, Jorritsma R, Davies CJ, Koets AP. Two-Way Calf to Dam Major Histocompatibility Class I Compatibility Increases Risk for Retained Placenta in Cattle. Am J Reprod Immunol (2012) 67(3):224-30. doi: 10.1111/j.1600-0897.2011.01085.x

128. Bertics SJ, Grummer RR, Cadorniga-Valino C, Stoddard EE. Effect of Prepartum Dry Matter Intake on Liver Triglyceride Concentration and Early Lactation. J Dairy Sci (1992) 75(7):1914-22. doi: 10.3168/jds.S00220302(92)77951-X

129. Borghesi L, Milcarek C. Innate Versus Adaptive Immunity: A Paradigm Past Its Prime? Cancer Res (2007) 67(9):3989-93. doi: 10.1158/0008-5472.CAN-07-0182

130. Rainard P, Riollet C. Innate Immunity of the Bovine Mammary Gland. Vet Res (2006) 37(3):369-400. doi: 10.1051/vetres:2006007

131. Ezzat Alnakip M, Quintela-Baluja M, Bohme K, Fernandez-No I, CaamanoAntelo S, Calo-Mata P, et al. The Immunology of Mammary Gland of Dairy Ruminants Between Healthy and Inflammatory Conditions. J Vet Med (2014) 2014:659801. doi: 10.1155/2014/659801

132. Sordillo LM. Mammary Gland Immunobiology and Resistance to Mastitis. Vet Clin North Am Food Anim Pract (2018) 34(3):507-23. doi: 10.1016/ j.cvfa.2018.07.005

133. Goldammer T, Zerbe H, Molenaar A, Schuberth HJ, Brunner RM, Kata SR, et al. Mastitis Increases Mammary mRNA Abundance of Beta-Defensin 5, Toll-Like-Receptor 2 (TLR2), and TLR4 But Not TLR9 in Cattle. Clin Diagn Lab Immunol (2004) 11(1):174-85. doi: 10.1128/CDLI.11.1.174-185.2004

134. Rainard P. Tackling Mastitis in Dairy Cows. Nat Biotechnol (2005) 23 (4):430-2. doi: 10.1038/nbt0405-430

135. Barrington GM, Besser TE, Davis WC, Gay CC, Reeves JJ, McFadden TB. Expression of Immunoglobulin G1 Receptors by Bovine Mammary Epithelial Cells and Mammary Leukocytes. J Dairy Sci (1997) 80(1):86-93. doi: 10.3168/jds.S0022-0302(97)75915-0

136. Shafer-Weaver KA, Pighetti GM, Sordillo LM. Diminished Mammary Gland Lymphocyte Functions Parallel Shifts in Trafficking Patterns During the Postpartum Period. Proc Soc Exp Biol Med Soc Exp Biol Med (1996) 212 (3):271-80. doi: 10.3181/00379727-212-44016

137. Larson BL, Heary HL Jr, Devery JE. Immunoglobulin Production and Transport by the Mammary Gland. J Dairy Sci (1980) 63(4):665-71. doi: 10.3168/jds.S0022-0302(80)82988-2

138. Vaughn DE, Bjorkman PJ. Structural Basis of pH-Dependent Antibody Binding by the Neonatal Fc Receptor. Structure (1998) 6(1):63-73. doi: 10.1016/S0969-2126(98)00008-2
139. Oliver SP, Sordillo LM. Udder Health in the Periparturient Period. J Dairy Sci (1988) 71(9):2584-606. doi: 10.3168/jds.S0022-0302(88)79847-1

140. Sordillo LM, Redmond MJ, Campos M, Warren L, Babiuk LA. Cytokine Activity in Bovine Mammary Gland Secretions During the Periparturient Period. Can J Vet Res = Rev Can Recherche Vet (1991) 55(3):298-301.

141. Surlis C, Earley B, McGee M, Keogh K, Cormican P, Blackshields G, et al. Blood Immune Transcriptome Analysis of Artificially Fed Dairy Calves and Naturally Suckled Beef Calves From Birth to 7 Days of Age. Sci Rep (2018) 8 (1):15461. doi: 10.1038/s41598-018-33627-0

142. Liebler-Tenorio EM, Riedel-Caspari G, Pohlenz JF. Uptake of Colostral Leukocytes in the Intestinal Tract of Newborn Calves. Vet Immunol Immunopathol (2002) 85(1-2):33-40. doi: 10.1016/S0165-2427(01)00404-4

143. Kessler EC, Bruckmaier RM, Gross JJ. Colostrum Composition and Immunoglobulin G Content in Dairy and Dual-Purpose Cattle Breeds. J Anim Sci (2020) 98(8):skaa237. doi: 10.1093/jas/skaa237

144. Wheeler TT, Hodgkinson AJ, Prosser CG, Davis SR. Immune Components of Colostrum and Milk-A Historical Perspective. J Mammary Gland Biol Neoplasia (2007) 12(4):237-47. doi: 10.1007/s10911-007-9051-7

145. Butler JE, Zhao Y, Sinkora M, Wertz N, Kacskovics I. Immunoglobulins, Antibody Repertoire and B Cell Development. Dev Comp Immunol (2009) 33 (3):321-33. doi: 10.1016/j.dci.2008.06.015

146. Stilwell G, Carvalho RC. Clinical Outcome of Calves With Failure of Passive Transfer as Diagnosed by a Commercially Available IgG Quick Test Kit. Can Vet $J=$ La Rev Vet Canadienne (2011) 52(5):524-6.

147. Chamorro MF, Cernicchiaro N, Haines DM. Evaluation of the Effects of Colostrum Replacer Supplementation of the Milk Replacer Ration on the Occurrence of Disease, Antibiotic Therapy, and Performance of Pre-Weaned Dairy Calves. J Dairy Sci (2017) 100(2):1378-87. doi: 10.3168/jds.2016-11652

148. Palczynski LJ, Bleach ECL, Brennan ML, Robinson PA. Appropriate Dairy Calf Feeding From Birth to Weaning: "It's an Investment for the Future". Animals: An Open Access J MDPI (2020) 10(1):116. doi: 10.3390/ ani10010116

149. Abuelo A, Cullens F, Hanes A, Brester JL. Impact of 2 Versus 1 Colostrum Meals on Failure of Transfer of Passive Immunity, Pre-Weaning Morbidity and Mortality, and Performance of Dairy Calves in a Large Dairy Herd. Animals: An Open Access J MDPI (2021) 11(3):782. doi: 10.3390/ani11030782

150. Lora I, Gottardo F, Bonfanti L, Stefani AL, Soranzo E, Dall'Ava B, et al. Transfer of Passive Immunity in Dairy Calves: The Effectiveness of Providing a Supplementary Colostrum Meal in Addition to Nursing From the Dam. Animal: An Int J Anim Biosci (2019) 13(11):2621-9. doi: 10.1017/ S1751731119000879

151. USDA A. A Guide to Calf Milk Replacers (2008). Available at: https://www. aphis.usda.gov/animal_health/nahms/dairy/downloads/bamn/BAMN08_ GuideMilkRepl.pdf.

152. Richeson JT, Hughes HD, Broadway PR, Carroll JA. Vaccination Management of Beef Cattle: Delayed Vaccination and Endotoxin Stacking. Vet Clin North Am Food Anim Pract (2019) 35(3):575-92. doi: 10.1016/ j.cvfa.2019.07.003

153. Saif LJ, Smith KL. Enteric Viral Infections of Calves and Passive Immunity. J Dairy Sci (1985) 68(1):206-28. doi: 10.3168/jds.S0022-0302(85)80813-4

154. Hodgins DC, Chattha KS, Vlasova AN, Parreno V, Corbeil LB, Renukaradhya GJ, et al. Mucosal Veterinary Vaccines: Comparative Vaccinology. In: Mestecky J, Lamm ME, McGhee JR, Bienenstock J, Mayer L, Strober W, editors. Mucosal Immunology, 4th ed. Atlanta, GA: Academic Press, Elsevier (2015). p. 1337-61.

155. Saif LJ, Fernandez FM. Group A Rotavirus Veterinary Vaccines. J Infect Dis (1996) 174(Suppl 1):S98-106. doi: 10.1093/infdis/174.Supplement_1.S98

156. Langel SN, Paim FC, Alhamo MA, Buckley A, Van Geelen A, Lager KM, et al. Stage of Gestation at Porcine Epidemic Diarrhea Virus Infection of Pregnant Swine Impacts Maternal Immunity and Lactogenic Immune Protection of Neonatal Suckling Piglets. Front Immunol (2019) 10:727. doi: 10.3389/ fimmu.2019.00727

157. Nugent G, Yockney IJ, Whitford J, Aldwell FE, Buddle BM. Efficacy of Oral BCG Vaccination in Protecting Free-Ranging Cattle From Natural Infection by Mycobacterium Bovis. Vet Microbiol (2017) 208:181-9. doi: 10.1016/ j.vetmic.2017.07.029

158. Buddle BM. Vaccination of Cattle Against Mycobacterium Bovis Tuberculosis (2001) 81(1-2):125-32. doi: 10.1054/tube.2000.0254 
159. Buddle BM, Wedlock DN, Denis M, Vordermeier HM, Hewinson RG. Update on Vaccination of Cattle and Wildlife Populations Against Tuberculosis. Vet Microbiol (2011) 151(1-2):14-22. doi: 10.1016/j.vetmic. 2011.02.021

160. Theurer ME, Larson RL, White BJ. Systematic Review and Meta-Analysis of the Effectiveness of Commercially Available Vaccines Against Bovine Herpesvirus, Bovine Viral Diarrhea Virus, Bovine Respiratory Syncytial Virus, and Parainfluenza Type 3 Virus for Mitigation of Bovine Respiratory Disease Complex in Cattle. J Am Vet Med Assoc (2015) 246 (1):126-42. doi: 10.2460/javma.246.1.126

161. Chase CC. Autogenous Vaccines: Current Use in the Field in the U.S. Cattle Hog Industry. Develop Biol (2004) 117:69-71.

162. Waltner-Toews D, Martin SW, Meek AH, McMillan I, Crouch CF. A Field Trial to Evaluate the Efficacy of a Combined Rotavirus-Coronavirus/ Escherichia Coli Vaccine in Dairy Cattle. Can J Comp Med: Rev Can Med Comparee (1985) 49(1):1-9.

163. Newcomer BW, Chamorro MF, Walz PH. Vaccination of Cattle Against Bovine Viral Diarrhea Virus. Vet Microbiol (2017) 206:78-83. doi: 10.1016/ j.vetmic.2017.04.003

164. Walz PH, Riddell KP, Newcomer BW, Neill JD, Falkenberg SM, Cortese VS, et al. Comparison of Reproductive Protection Against Bovine Viral Diarrhea Virus Provided by Multivalent Viral Vaccines Containing Inactivated Fractions of Bovine Viral Diarrhea Virus 1 and 2. Vaccine (2018) 36 (26):3853-60. doi: 10.1016/j.vaccine.2018.04.005

165. Lalsiamthara J, Lee JH. Development and Trial of Vaccines Against Brucella. J Vet Sci (2017) 18(S1):281-90. doi: 10.4142/jvs.2017.18.S1.281

166. Uzal FA. Evidence-Based Medicine Concerning Efficacy of Vaccination Against Clostridium Chauvoei Infection in Cattle. Vet Clin North Am Food Anim Pract (2012) 28(1):71-7, viii. doi: 10.1016/j.cvfa.2011.12.006

167. Zaragoza NE, Orellana CA, Moonen GA, Moutafis G, Marcellin E. Vaccine Production to Protect Animals Against Pathogenic Clostridia. Toxins (2019) 11(9):525. doi: 10.3390/toxins11090525

168. Moussa IM, Ali MS, Hessain AM, Kabli SA, Hemeg HA, Selim SA. Vaccination Against Corynebacterium Pseudotuberculosis Infections Controlling Caseous Lymphadenitis (CLA) and Oedematousskin Disease. Saudi J Biol Sci (2016) 23(6):718-23. doi: 10.1016/j.sjbs.2016.06.005

169. Ismail ZB. Mastitis Vaccines in Dairy Cows: Recent Developments and Recommendations of Application. Vet world (2017) 10(9):1057-62. doi: 10.14202/vetworld.2017.1057-1062

170. Ayalew S, Confer AW, Shrestha B, Wilson AE, Montelongo M. Proteomic Analysis and Immunogenicity of Mannheimia Haemolytica Vesicles. Clin Vaccine Immunol: CVI (2013) 20(2):191-6. doi: 10.1128/CVI.00622-12

171. Nagai K, Otomaru K, Ogawa R, Oishi S, Wataya K, Honkawa Y, et al. Effect of Combined Vaccination for Pasteurella Multocida, Mannheimia Haemolytica, and Histophilus Somni to Prevent Respiratory Diseases in Young Japanese Black Calves in the Field. J Vet Med Sci (2019) 1081 (9):1355-8. doi: 10.1292/jvms.19-0256

172. Foster D, Jacob M, Stowe D, Smith G. Exploratory Cohort Study to Determine If Dry Cow Vaccination With a Salmonella Newport Bacterin Can Protect Dairy Calves Against Oral Salmonella Challenge. J Vet Internal Med (2019) 33(4):1796-806. doi: 10.1111/jvim.15529

173. Fulton RW. Bovine Respiratory Disease Research (1983-2009). Anim Health Res Rev (2009) 10(2):131-9. doi: 10.1017/S146625230999017X

174. Constable PD. Treatment of Calf Diarrhea: Antimicrobial and Ancillary Treatments. Vet Clin North Am Food Anim Pract (2009) 25(1):101-20. doi: 10.1016/j.cvfa.2008.10.012

175. De Briyne N, Atkinson J, Pokludova L, Borriello SP. Antibiotics Used Most Commonly to Treat Animals in Europe. Vet Rec (2014) 175(13):325. doi: $10.1136 /$ vr.102462
176. Nickell JS, White BJ. Metaphylactic Antimicrobial Therapy for Bovine Respiratory Disease in Stocker and Feedlot Cattle. Vet Clin North Am Food Anim Pract (2010) 26(2):285-301. doi: 10.1016/j.cvfa.2010.04.006

177. Lhermie G, Toutain PL, El Garch F, Bousquet-Melou A, Assie S. Implementing Precision Antimicrobial Therapy for the Treatment of Bovine Respiratory Disease: Current Limitations and Perspectives. Front Vet Sci (2017) 4:143. doi: 10.3389/fvets.2017.00143

178. Morley PS, Apley MD, Besser TE, Burney DP, Fedorka-Cray PJ, Papich MG, et al. Antimicrobial Drug Use in Veterinary Medicine. J Vet Internal Med (2005) 19(4):617-29. doi: 10.1111/j.1939-1676.2005.tb02739.x

179. Guerra-Maupome M, Vang DX, McGill JL. Aerosol Vaccination With Bacille Calmette-Guerin Induces a Trained Innate Immune Phenotype in Calves. PloS One (2019) 14(2):e0212751. doi: 10.1371/journal.pone.0212751

180. Vlasova AN, Kandasamy S, Chattha KS, Rajashekara G, Saif LJ. Comparison of Probiotic Lactobacilli and Bifidobacteria Effects, Immune Responses and Rotavirus Vaccines and Infection in Different Host Species. Vet Immunol Immunopathol (2016) 172:72-84. doi: 10.1016/j.vetimm.2016.01.003

181. Harp JA, Jardon P, Atwill ER, Zylstra M, Checel S, Goff JP, et al. Field Testing of Prophylactic Measures Against Cryptosporidium Parvum Infection in Calves in a California Dairy Herd. Am J Vet Res (1996) 57(11):1586-8.

182. Weese JS, Rousseau J. Evaluation of Lactobacillus Pentosus WE7 for Prevention of Diarrhea in Neonatal Foals. J Am Vet Med Assoc (2005) 226 (12):2031-4. doi: 10.2460/javma.2005.226.2031

183. von Buenau R, Jaekel L, Schubotz E, Schwarz S, Stroff T, Krueger M. Escherichia Coli Strain Nissle 1917: Significant Reduction of Neonatal Calf Diarrhea. J Dairy Sci (2005) 88(1):317-23. doi: 10.3168/jds.S0022-0302(05) 72690-4

184. Vega C, Bok M, Saif L, Fernandez F, Parreno V. Egg Yolk IgY Antibodies: A Therapeutic Intervention Against Group A Rotavirus in Calves. Res Vet Sci (2015) 103:1-10. doi: 10.1016/j.rvsc.2015.09.005

185. Mine Y, Kovacs-Nolan J. Chicken Egg Yolk Antibodies as Therapeutics in Enteric Infectious Disease: A Review. J Med Food (2002) 5(3):159-69. doi: $10.1089 / 10966200260398198$

186. Abbas AT, El-Kafrawy SA, Sohrab SS, Azhar EIA. IgY Antibodies for the Immunoprophylaxis and Therapy of Respiratory Infections. Hum Vaccines Immunother (2019) 15(1):264-75. doi: 10.1080/21645515.2018.1514224

187. Ikemori $\mathrm{Y}$, Ohta M, Umeda K, Icatlo FCJr., Kuroki M, Yokoyama H, et al. Passive Protection of Neonatal Calves Against Bovine Coronavirus-Induced Diarrhea by Administration of Egg Yolk or Colostrum Antibody Powder. Vet Microbiol (1997) 58(2-4):105-11. doi: 10.1016/S0378-1135(97)00144-2

188. Ballou MA. CASE STUDY: Effects of a Blend of Prebiotics, Probiotics, and Hyperimmune Dried Egg Protein on the Performance, Health, and Innate Immune Responses of Holstein Calves. Prof Anim Sci (2011) 27(3):262-8. doi: 10.15232/S1080-7446(15)30483-6

189. Muscato TV, Tedeschi LO, Russell JB. The Effect of Ruminal Fluid Preparations on the Growth and Health of Newborn, Milk-Fed Dairy Calves. J Dairy Sci (2002) 85(3):648-56. doi: 10.3168/jds.S0022-0302(02) $74119-2$

Conflict of Interest: The authors declare that the research was conducted in the absence of any commercial or financial relationships that could be construed as a potential conflict of interest.

Copyright (c) 2021 Vlasova and Saif. This is an open-access article distributed under the terms of the Creative Commons Attribution License (CC BY). The use, distribution or reproduction in other forums is permitted, provided the original author $(s)$ and the copyright owner(s) are credited and that the original publication in this journal is cited, in accordance with accepted academic practice. No use, distribution or reproduction is permitted which does not comply with these terms. 